Hydrol. Earth Syst. Sci. Discuss., doi:10.5194/hess-2016-627, 2016

Manuscript under review for journal Hydrol. Earth Syst. Sci.

Published: 6 December 2016

\title{
A curve number approach to formulate hydrological response units within distributed hydrological modelling
}

\author{
Eleni Savvidou ${ }^{1}$, Andreas Efstratiadis², Antonis D. Koussis ${ }^{3}$, Antonis Koukouvinos ${ }^{2}$, Dimitrios \\ Skarlatos ${ }^{1}$ \\ $5{ }^{1}$ Department of Civil Engineering and Geomatics, Faculty of Engineering and Technology, Cyprus University of \\ Technology, Limassol, 3036, Cyprus \\ ${ }^{2}$ Department of Water Resources and Environmental Engineering, School of Civil Engineering, National Technical \\ University of Athens, Zographou, 15780, Greece \\ ${ }^{3}$ Institute for Environmental Research and Sustainable Development, National Observatory of Athens, 15236 P. Penteli, \\ Greece
}

Correspondence to: Eleni Savvidou (em.savvidou@edu.cut.ac.cy)

\begin{abstract}
We propose a systematic framework for delineating Hydrological Response Units (HRUs), based on a modified Curve Number $(\mathrm{CN})$ approach. The $\mathrm{CN}$-value accounts for three major physiographic characteristics of a river basin, by means of classes of soil permeability, land use/land cover characteristics, and drainage capacity. A semi-automatic procedure

15 in a GIS environment allows producing basin maps of distributed $\mathrm{CN}$-values as the product of the three classified layers. The map of $\mathrm{CN}$-values is used in the context of model parameterization, in order to identify the essential number and spatial extent of HRUs and, consequently, the number of control variables of the calibration problem. The new approach aims at reducing the subjectivity introduced by the definition of HRUs, and simultaneously at providing parsimonious modelling schemes. In particular, the $\mathrm{CN}$-based parameterization (1) allows the user to assign as many parameters as can be supported

20 by the available hydrological information, (2) associates the model parameters with anticipated basin responses, as quantified in terms of $\mathrm{CN}$ classes across HRUs, and (3) reduces the effort for model calibration, simultaneously ensuring good predictive capacity. The advantages of the proposed framework are demonstrated in the hydrological simulation of Nedontas river basin, Greece, in which parameterizations of different complexities are employed in a recently improved version of the HYDROGEIOS modelling framework.
\end{abstract}

\section{Introduction}

According to their spatial scale of process representation, hydrological models are generally classified from lumped to distributed. In the first approach, the watershed is considered as a single unit that responds homogeneously to its spatiallyaveraged meteorological inputs. That model structure is quite simple, since the hydrological processes are conceptualized through hydraulic analogues (e.g., linear reservoirs), but given that the model parameters are only associated with the macroscopic properties of the watershed as a whole, they have limited physical background. In this context, the unique 
Hydrol. Earth Syst. Sci. Discuss., doi:10.5194/hess-2016-627, 2016

Manuscript under review for journal Hydrol. Earth Syst. Sci.

Published: 6 December 2016

(c) Author(s) 2016. CC-BY 3.0 License.

means to establish a lumped modelling scheme of satisfactory predictive capacity is to infer its parameters through calibration, aiming to reproduce as closely as possible the observed responses of the basin.

In contrast, distributed models explicitly account for the spatial heterogeneity across the watershed, in terms of physiographic characteristics, weather inputs, hydrological processes and boundary conditions. The representation of

5 heterogeneity is employed via discretization of the model domain in finely-resolved computational units (e.g., grid cells). The fundamental laws of hydraulics and semi-empirical hydrological formulae are applied at each spatial unit, which allows, in theory, to directly estimate all model parameters from field data. Due to their bottom-up basis, which takes advantage of the significant advances in understanding the hydrological processes at the micro (point, continuum)-scale, fully-distributed models are also identified as "physically-based” (Beven, 1989).

10 The advantages and disadvantages of the two approaches have been widely discussed in the literature (Ajami et al., 2004; Boyle et al., 2001; Nalbantis et al., 2011). It is obvious that lumped conceptual models cannot represent the spatiotemporal variability of the hydrological processes at basin level, while fully-distributed models are data and time-demanding. Yet, the most important issue is that, despite their different backgrounds, both approaches suffer from uncertainties related with the estimation of their parameters. In fact, from the introduction of physically- or process-based models, the hydrological

15 community has criticized them as overly complex and over-parameterized and difficult to use, while strongly disputing their ability to apply parameters that are directly measured in the field (observable), without some kind of calibration (e.g. Beven, 1989; Eckhardt and Arnold, 2001; Fatichi et al., 2016; Refsgaard, 1997). The reasonable argument behind this criticism is that the physical properties are measured at the point scale, while the parameters are assigned to the grid-cell scale, and are thus by definition conceptual. Hence, given that distributed models comprise so many parameters, they are too vulnerable

20 against the well-known shortcomings of calibration, i.e. the equifinality problem (Beven and Binley, 1992). However, it has been argued that in some situations the use of process-based models is necessary, while in a certain class of problems they are the most appropriate tool to use, especially in cases where knowledge of flow paths or distributed state variables and/or preservation of physical constraints is important (Fatichi et al., 2016).

For many problems of the everyday practice requiring flow predictions at a relatively small number of points across the river

25 network, semi-distributed models are broadly recognized as a good compromise between lumped and fully-distributed approaches (Boyle et al., 2001). The key concept is to divide the watershed into a number of sub-basins and propagate the runoff generated from each sub-basin through the river network (and similarly for the subsurface water processes). Although at the sub-basin scale the modelling remains lumped (except for some specific cases, in which sub-basins are further divided in smaller units), at the watershed scale the heterogeneities are partially accounted for by assigning different meteorological

30 inputs and different properties at each sub-basin. Another advantage of semi-distributed schemes is the representation of flow routing processes, which is of key importance when fine time steps are employed (e.g., in flood modelling).

The configuration of a semi- or fully-distributed model and the associated level of complexity are determined by the user. This task involves two separate issues, the discretization of the watershed and the parameterization of the model. The 
Hydrol. Earth Syst. Sci. Discuss., doi:10.5194/hess-2016-627, 2016

Manuscript under review for journal Hydrol. Earth Syst. Sci.

Published: 6 December 2016

(c) Author(s) 2016. CC-BY 3.0 License.

discretization refers to the delineation of the spatial units (typically, grid cells in the case of distributed, and sub-basins in the case of semi-distributed models), while the parameterization refers to the spatial assignment of the model parameters.

During the long history of hydrological models, these two topics have been handled in many different ways. In particular, the discretization of the watershed predetermines the aggregation patterns of spatial information, i.e. the size and shape of computational elements, and controls the associated topographic parameter values such as slope, aspect etc. On the other hand, different delineations of the stream network connectivity and hillslope size affect, and can often misrepresent rainfallrunoff processes on hillslopes and across channels. Consequently, the watershed subdivision has the potential to affect the output of hydrological modeling (Zhang et al., 2013). This relates to the ongoing theoretical debate about the optimal level of watershed discretization that adequately represents the spatial heterogeneity of a watershed (Beven, 1993), a subject that has

10 received considerable attention in the literature from the early steps of distributed modelling. For instance, Hromadka (1986) states that "Arbitrary subdivision of the watershed into subareas should generally be avoided. ... an increase in the watershed subdivision does not necessarily increase the modeling 'accuracy' but rather transfers the model's reliability from the calibrated unit hydrograph and lag relationships to the unknown reliability of the several flow routing submodels used to link together the several subareas".

15 While it is common practice to partition a watershed into smaller units (e.g., sub-basins), it is not easy to identify a strictly optimal spatial scale. It is accepted that, for a given watershed and a given data set, the sub-watershed size should be adapted to the modelling objectives, as the latter determine the dominant hydrological processes considered in the simulation (Dehotin and Braud, 2008). It is feasible to represent the landscape heterogeneity through small sub-watersheds; for large watersheds, however, a fine resolution is often prevented, mainly by high data requirements. Therefore, when hydrological

20 models are employed in meso- and large-scale watersheds, significant simplifications are required, in order to aggregate the spatial heterogeneity and its associated parameters at various levels of watershed subdivision (Cho and Olivera, 2009).

Increasing the number of sub-watersheds definitely increases input data preparation, computational time and calibration effort; therefore, the sub-watershed-average inputs generated from discrete gauging stations vary with different watershed subdivisions (Han et al., 2014). Few works have been reported in the literature to explain the variations in the distributed model inputs as a result of various levels of watershed subdivision. For instance, Li et al. (2014) report that the precipitation input pattern in the hydrological modelling was significantly affected by watershed subdivision. Savenije (2010) proposed an approach between complex distributed and simple lumped modeling, aiming to find the right level of simplicity while avoiding over-simplification. He presented a process-based, but conceptual approach, where topography is used as a key for classification, retaining maximum simplicity whilst taking into account observable landscape characteristics. A new terrain

30 descriptor, the Height Above the Nearest Drainage (HAND) based on SRTM-DEM data (Rennó et al., 2008) has also been employed in landscape classification, revealing strong correlation between soil water conditions and topography, while Donnelly et al. (2016) found the strongest relationships to be between upstream area, proportion of upstream agricultural land, elevation, mean precipitation, and mean temperature. Gharari et al. (2011) assessed the performance and sensitivity of 
Hydrol. Earth Syst. Sci. Discuss., doi:10.5194/hess-2016-627, 2016

Manuscript under review for journal Hydrol. Earth Syst. Sci.

Published: 6 December 2016

(c) Author(s) 2016. CC-BY 3.0 License.

HAND-based landscape classification framework compared with other several classification indicators. They reported that HAND and surface slope appeared to be the stronger indicators for different dominant hydrological processes.

Over the years, several watershed subdivision approaches have been developed and tested using a variety of well-established hydrological models. An obvious approach is to divide the watershed into its natural sub-watersheds based on topography 5 extracted from a Digital Elevation Model (DEM). This configuration preserves the watershed's natural boundaries, flowpaths and channels for realistic water routing (Bingner et al., 1997; Boyd et al., 1979; Goodrich, 1992; Goodrich et al., 1988; Norris, 1992; Norris and Haan, 1993; Zhang et al., 2004). The concepts of Critical Source Area (CSA; Arabi et al., 2006; Cho et al., 2010; FitzHugh and Mackay, 2000; Kalin et al., 2003; Kumar and Merwade, 2009; Muleta et al., 2007; Thieken et al., 1999), Threshold Drainage Area (TDA; Nour et al., 2008) and Aggregated Simulation Area (ASA; Kite, 1997) have also

10 been used to delineate sub-watersheds within semi-distributed models. Moving from semi- to fully-distributed modelling, more detailed delineation concepts are employed, such as grid elements, representative elementary areas (REA), and representative elementary watershed (REW). In particular, the equally-spaced grid approach refers to the subdivision of the watershed into grid elements, each representing the dominant land use and soil type. The effects of grid-cell size on surface runoff and model accuracy have been investigated by Bathurst (1986); Bruneau et al. (1995); Manguerra and Engel (1998);

15 Molnar and Julien (2000); Tao and Kouwen (1989) and Zhang and Montgomery (1994). The REA concept, introduced by Wood et al. (1988) and investigated by Sasowsky and Gardner (1991), considers a watershed as composed of numerous (infinite) points (REAs), at which evaporation, infiltration and runoff fluctuate. In the REW approach on the other hand (Reggiani et al., 1998, 1999, 2000; Reggiani and Rientjes, 2005), the point-scale equations of mass, momentum and energy conservation are integrated over the REW and mapped on the large scale.

20 Significant attention is given to the concept of hydrologic response units (HRU) over the last two decades. HRUs represent areas of the watershed with similar land use and soil characteristics. Their implementation is much simpler, since there is no interaction or topological connection between the HRUs; thus, runoff from each HRU is calculated separately and summed together to determine the total runoff from each sub-basin. Several HRU delineation methodologies developed and adopted by semi- and by fully-distributed hydrological models are synoptically discussed in section 3, after presenting the research scope of this work, which is intimately related to the HRU concept.

\section{Scope of research}

The aim of this research is to propose and test a systematic framework for delineating HRUs, based on a modified Curve Number $(\mathrm{CN})$ approach. The $\mathrm{CN}$-value accounts for three major physiographic characteristics of the river basin, by means of classes of: (a) soil permeability, evaluated according to the mechanical properties of the soil and the unsaturated zone, and the dominant geological formations (different criteria are employed in urbanized areas); (b) land use/land cover characteristics, typically expressed in terms of vegetation density; and (c) drainage capacity, evaluated according to the geomorphological characteristics of the basin (mainly the terrain slope) and the existence of runoff retention structures. A 
Hydrol. Earth Syst. Sci. Discuss., doi:10.5194/hess-2016-627, 2016

Manuscript under review for journal Hydrol. Earth Syst. Sci.

Published: 6 December 2016

(c) Author(s) 2016. CC-BY 3.0 License.

semi-automatic procedure in a GIS environment allows producing basin maps of distributed $\mathrm{CN}$-values as the combination of the three classified layers. The map of $\mathrm{CN}$-values is used in the context of model parameterization, to identify the essential number and spatial extent of HRUs and, consequently, the number of control variables of the calibration problem. The new approach aims, on one hand at reducing the subjectivity introduced by the definition of HRUs, and at providing

5 parsimonious modelling schemes on the other.

The advantages of the proposed framework are demonstrated in the hydrological simulation of Nedontas river basin, Greece, in which parameterizations of different complexities are employed in a recently improved version of the HYDROGEIOS model, which is built upon the HRU concept (Efstratiadis et al., 2008; Nalbantis et al., 2011). The outcomes of the case study highlight that our framework (1) allows the user to assign as many parameters as can be supported by the available

10 hydrological information, (2) associates the model parameters with anticipated basin responses, as quantified in terms of $\mathrm{CN}$ classes across HRUs, and (3) reduces the effort for model calibration, simultaneously ensuring good predictive capacity.

\section{Hydrological Response Units}

The concept of hydrological response units was first introduced by Leavesley et al. (1983), who delineated topographicstream-segment-based HRUs for storm hydrograph simulations through the PRMS hydrologic model. In this approach, an

15 HRU is considered to be the equivalent of a flow plane or delineated as several flow planes. However, the key assumption of homogeneity in HRUs was asserted by Flügel (1995), who defined HRUs as "distributed, heterogeneously structured areas with common land use and pedo-topo-geological associations controlling their unique hydrological dynamics". Such approach is justified by the fact that the dynamics of hydrological processes within an HRU vary only by a small amount compared to the dynamics among different HRUs. The concept of homogeneous HRUs was applied on the River Bröl basin

$20\left(216 \mathrm{~km}^{2}\right)$, Germany, using the PRMS/MMS model (Leavesley and Stannard, 1995). A total of 23 HRUs were delineated and tested using a 20-year hydro-meteorological data series of daily values. It was found that HRUs are a reliable means for regional hydrological watershed modeling, allowing spatial up- and down-scaling (Flügel, 1995, 1997). Bongartz (2003) compared to topographic-based (Leavesley et al., 1983) and homogeneous HRUs (Flügel, 1995), and reported that, for watersheds with areas less than $200 \mathrm{~km}^{2}$, homogeneous HRUs provided better representation of the watershed processes.

25 A variation of the homogeneous HRU concept requires threshold specification for land cover, soil and slope classes, which is then used to delineate HRUs (Neitsch et al., 2002; Srinivasan et al., 2000). More specifically, the watershed is divided into several sub-basins that are further divided into discontinuous land masses, delineated through aggregation, according to userdefined thresholds for land use, soil type and slope ranges within each sub-watershed; this is followed by a GIS-based spatial overlay scheme, resulting into "unique combination" HRUs with homogeneous characteristics, representing percentages of

30 the sub-basin area that contribute differently to the entire watershed responses. The use of thresholds results in apparent loss of information, so it is suggested that thresholds should only be applied when the number of HRUs delineated results in acceptable computation costs (Gitau, 2003). This unique combination HRU concept has been adopted and widely used by 
Hydrol. Earth Syst. Sci. Discuss., doi:10.5194/hess-2016-627, 2016

Manuscript under review for journal Hydrol. Earth Syst. Sci.

Published: 6 December 2016

SWAT (Arnold et al., 1993; Neitsch et al., 2005). While the incorporation of HRUs has allowed SWAT the flexibility to adapt from field plots to entire river basins, the fact that HRUs are used in a non-spatial manner, i.e. they are not identified spatially within simulations, is regarded as key weakness of the model (Gassman, 2008; Gassman et al., 2007).

However, in most distributed hydrological models, the river basin is assumed to be an assembly of discrete entities (typically grid cells), with different properties, that contribute differently to its responses. Some of these properties are in fact parameters, since they cannot be determined by field measurements at the small-scale (although physically-based approaches treat them as known properties rather than as unknown quantities; cf. Refsgaard, 1997). Thus, HRUs denote spatial elements of pre-determined geometry, while the parameterization of the hydrological processes is dictated by the model discretization (Efstratiadis et al., 2008; Nalbantis et al., 2011; Daniel et al., 2011). A well-known example is the HEC-HMS model, which

10 considers different parameters per sub-basin, thus the number of parameters increase linearly with the number of sub-basins. HRUs can also be defined as the product of separate partitions that account for different watershed properties such as land use, soil permeability, terrain slope, etc. This product is known as common refinement of the partitions, while the related procedure in GIS is often called "union of layers". Using an appropriate classification of the above properties, the number of HRUs is adjusted and, thus, so is the number of parameters describing the soil hydrological mechanisms. We note that the

15 number of HURs is determined as the product of the parent layer classes, i.e., if $n_{j}$ is the number of classes corresponding to the $i$-th layer, then this number will be $N=\prod n_{j}$. The "union of layers" concept has been adopted for HYDROGEIOS (Efstratiadis et al., 2008; Nalbantis et al., 2011), a GIS-based modelling system that provides a holistic framework aiming to combine hydrological and hydrogeological simulations, in an attempt to make schematization and parameterization two clearly independent procedures. In this approach, HRUs do not represent contiguous geographical areas (while sub-basins

20 are by definition contiguous), but basin partitions with common characteristics (and thus common parameter values). The union of each sub-basin and each HRU represents the minor geographical element in the modelling procedure. This element is fed by the rainfall and potential evapotranspiration of the corresponding sub-basin and responds according to the parameter values of the corresponding HRU. The shape of this non-contiguous element is not of interest; the only required geographical information is its area. At each time step, the runoff generated by each HRU is integrated over the corresponding sub-basin. It is important to note here that there are no restrictions on the number of HRUs. In the case of limited information for model calibration, one can define only two or three HRUs, in order to represent the heterogeneity of the physiographic characteristics of the basin and associated hydrologic processes, while this number can increase as more data become available to identify the spatial distribution of model parameters. The whole approach is very flexible; there are no restrictions on the configuration of HRUs, while the availability of data (critical for calibration) does not influence the

30 watershed schematization, i.e. the delineation of sub-basins: one can use a large number of sub-basins (if, e.g., one wishes to represent the runoff across the basin in a particular spatial detail) and at the same time keep a parsimonious parameterization. However, the fact that the number of HRUs is disengaged from the spatial discretization of the watershed does not necessarily ensure efficient and parsimonious parameterizations. In this regard, our work aims to provide empirical guidelines for formulating HRUs in the context of (semi-)distributed hydrological modelling, based on a systematic approach 
Hydrol. Earth Syst. Sci. Discuss., doi:10.5194/hess-2016-627, 2016

Manuscript under review for journal Hydrol. Earth Syst. Sci.

Published: 6 December 2016

that takes advantage of the well-known curve number concept. The new approach comprises a semi-automated procedure for determining the $\mathrm{CN}$ parameter in a GIS environment, taking into account additional information with respect to the classical SCS-CN method. In particular, the estimation of the CN parameter is based on three levels of spatial information that refer to the key factors interacting in the generation of surface runoff. Outcome of this procedure is the production of maps of

distributed values of $\mathrm{CN}$ that are next used for delineating HRUs across the river basin. This new CN-approach for HRU delineation is tested and compared to the unique combination and union of layers methods explained above within the HYDROGEIOS modelling framework.

\section{CN approach for HRU delineation}

\subsection{The standard CN approach and its shortcomings}

10 The curve number, $\mathrm{CN}$, is a conceptual parameter, ranging from 1 to 100, that was introduced by the Soil Conservation Service (SCS, 1972) (now, the Natural Resources Conservation Service) in an attempt to capture in a single value the physiographic characteristics of a catchment that are associated with runoff generation. The curve number is widely used in the context of the homonymous rainfall-runoff modelling approach, and depends on soil and land characteristics, as well as on the soil moisture present in the soil profile before the start of a rainfall event. In particular, the method considers three

15 antecedent soil moisture (AMC) conditions (type I: dry, type II: moderate, type III: wet), depending on the cumulative 5-day antecedent rainfall and the season category (dormant or growing). CN values for AMC II conditions and the typically-used ratio of initial abstraction losses, i.e. $20 \%$ of maximum potential retention (henceforth referred to as reference conditions) are determined from lookup tables, accounting for several combinations of land use/land cover characteristics and four hydrological soil types. The reference $\mathrm{CN}$ values have been obtained experimentally from rainfall and runoff measurements

20 over a wide range of geographic, soil, and land management conditions.

An important shortcoming of the standard $\mathrm{CN}$ method is that it does not take into account the effect of slope. In fact, the CN values provided in the standard SCS tables were mainly identified from small agricultural watersheds, in which slope has minor only impact on the rainfall-runoff transformation. However, in the general case, the relief characteristics affect greatly the hydrological processes of a watershed. Steep slopes cause reduction of initial abstractions, decrease in infiltration, and

25 reduction of the recession time of overland flow, which in turn results in increased surface runoff. Today it is accepted that the reference $\mathrm{CN}$ values are applicable for terrain slopes around $5 \%$, and several researchers have proposed empirical formulae for adjusting the CN-values to slope (Huang et al., 2006; Xu et al., 2011).

Moreover, the classification of soil characteristics does not cover adequately the entire range of permeability characteristics of the geological formations that are dominant in several areas worldwide. For instance, several Mediterranean watersheds

30 lie in karst terrain, resulting in very low runoff rates. According to the typical classification of SCS, karst basins should be classified in group A, representing sand, loamy sand or sandy loam types of soils. Reported experience with the use of the SCS approach for flood estimations is such basins indicates that the associated CN values were quite overestimated; in fact, 
Hydrol. Earth Syst. Sci. Discuss., doi:10.5194/hess-2016-627, 2016

Manuscript under review for journal Hydrol. Earth Syst. Sci.

Published: 6 December 2016

(c) Author(s) 2016. CC-BY 3.0 License.

much lower values, of about 30-40, should be employed to represent the significant infiltration losses in such basins (Efstratiadis et al., 2014a).

A common difficulty with CN derivation from SCS tabular data is the subjectivity involved in the determination of representative parameter values, through combining land cover classes and hydrological soil groups. The estimations are

5 mainly based on qualitative information rather than on numerical criteria, while for several common cases the recommended values range too widely. Therefore, different interpretations may be given for the same land cover and soil data, thus resulting in significant uncertainty in the determination of $\mathrm{CN}$-values.

\subsection{Novel GIS-based framework for CN estimation}

Accounting for the above issues, we propose a novel framework for $\mathrm{CN}$ assessment, based on the categorization of three

10 (instead of two) physiographic characteristics, each one comprising five classes: water permeability (hydraulic conductivity) of soil and near-surface geologic strata, henceforth referred to as permeability, land use/cover, and drainage capacity. Geographical data used for the production of the associated thematic layers include a hydro-lithological or soil map, a land use/cover map, a terrain slope map, and any other relevant information. In urban or suburban basins, information on the building features is also required, as well as other relevant urban features.

15 Permeability classifications in natural (non-urban) basins relate to the characteristics associated with the mechanical properties of the soil and unsaturated zone (e.g., horizontal and vertical hydraulic conductivity) that affect the infiltration, interflow and percolation mechanisms. Based on hydro-lithological or soil maps and depending on the predominant soil type, underlying geological formation and structures (for urban or suburban areas), the permeability class of the sub-basin is first described as very high, high, moderate, low or very low (Table S1). In urban basins, the corresponding classification is

20 defined by the density of structures, building features and open space development. A ranking from 1 to 5 is then assigned, where index 1 refers to very high-permeability substrata (e.g., karst) and 5 to very low-permeability substrata (e.g., dense rocks). Residential areas range from class 3 to 5, according to their built density.

Vegetation classes are formulated according to the characteristics related to precipitation retention mechanisms, soil roughness and filtration capacity, e.g. due to root zone growth. Based on a relevant land use map (e.g. CORINE Land Cover

25 Map), the vegetation class of the sub-basins is first described as dense, moderate, undergrowth, sparse or zero (Table S2). A ranking from 1 to 5 is then assigned, where index 1 refers to dense vegetation class (e.g., evergreen forests) and 5 to bare soil. It is recommended that burned areas be classified under one category with respect to their original condition; for instance, a burned coniferous forest should be classified as moderate vegetation class, thus assigning rank 2 instead of 1 .

The drainage capacity of the soil depends on geomorphological characteristics (topography, slope), the development of the

30 drainage network, and the existence of runoff regulation systems across the basin (e.g., land reclamation works, retention structures, sewer networks). The drainage capacity class of the sub-basins is first described as negligible, low, moderate, high and very high, and then a ranking from 1 to 5 is assigned (Table S3). In the absence of other information, the drainage capacity ranks are exclusively assigned on the basis of five terrain slope categories, given that terrain slope is an easily- 
Hydrol. Earth Syst. Sci. Discuss., doi:10.5194/hess-2016-627, 2016

Manuscript under review for journal Hydrol. Earth Syst. Sci.

Published: 6 December 2016

(c) Author(s) 2016. CC-BY 3.0 License.

retrieved property through typical DEM processing. Rank 1 is assigned to practically horizontal areas, while rank 5 is assigned to slopes over $30 \%$.

According to the above classifications, for a given area are assigned the dominant classes of permeability, land use/cover and drainage capacity, as well as the corresponding indices $i_{\mathrm{PERM}}, i_{\mathrm{VEG}}$ and $i_{\mathrm{SLOPE}}$, ranging from 1 to 5 (Table 1 ); however, if necessary, non-integer values may also be assigned to ensure more detailed classifications. Based on these characteristic values, we estimate the representative value of $\mathrm{CN}$ through the empirical relationship:

$\mathrm{CN}=10+9 \times i_{\mathrm{PERM}}+6 \times i_{\mathrm{VEG}}+3 \times i_{\mathrm{SLOPE}}$

The above formula has been extracted and validated according to average $\mathrm{CN}$-values obtained from the analysis of numerous flood events in a number of experimental river basins in Greece and Cyprus (Efstratiadis et al., 2014b). The minimum value of $\mathrm{CN}$ parameter is 28 , while the maximum is 100 . The former refers to the extreme case of areas with very high permeability, dense vegetation and negligible drainage capacity, while the latter is by definition applicable to areas covered by water bodies (rivers, lakes etc.), where all rainfall is converted to runoff.

Table 1: Coding of physiographic characteristics for the estimation of parameter CN for reference conditions (AMC type II and initial abstraction ratio $20 \%$ ).

\begin{tabular}{lclclc}
\hline Permeability Class & $i_{\text {PERM }}$ & Vegetation Class & $i_{\text {VEG }}$ & Drainage Capacity Class & $i_{\text {SLOPE }}$ \\
\hline Very High & 1 & Dense & 1 & Negligible & 1 \\
High & 2 & Moderate & 2 & Low & 2 \\
Moderate & 3 & Low & 3 & Moderate & 3 \\
Low & 4 & Sparse & 4 & High & 4 \\
Very Low & 5 & Zero & 5 & Very High & 5 \\
\hline
\end{tabular}

15

We note that, although the above procedure is applicable even to large reference areas (e.g., watersheds, sub-basins), it is recommended to take advantage of GIS facilities, allowing for fine spatial resolutions. In this respect, our proposed framework is mainly referred to the grid-cell scale; thus, the input data for $\mathrm{CN}$ estimation is provided by means of raster data for the three aforementioned indices. Based on the $\mathrm{CN}$ values calculated for each cell of the reference surface, a map is produced showing the spatial distribution of the $\mathrm{CN}$ parameter. The configuration process of the $\mathrm{CN}$-parameter map within a GIS environment is shown in Fig. 1, where raster layers of permeability, vegetation density and slope indices, with values from 1 to 5, are overlaid, to produce a raster map of distributed values of $\mathrm{CN}$ parameter for the reference area of interest. 
Hydrol. Earth Syst. Sci. Discuss., doi:10.5194/hess-2016-627, 2016

Manuscript under review for journal Hydrol. Earth Syst. Sci.

Published: 6 December 2016

(c) Author(s) 2016. CC-BY 3.0 License.
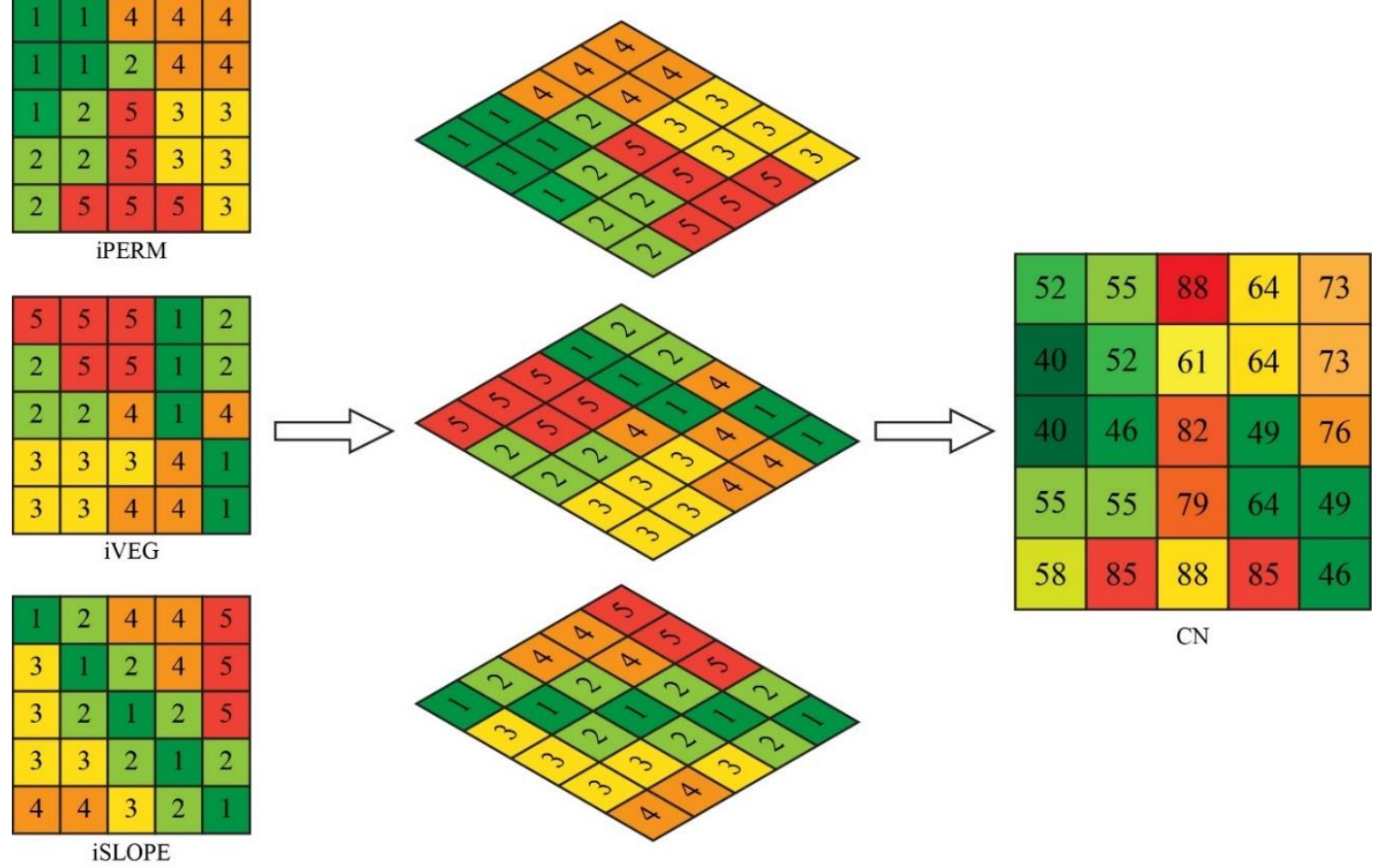

$\mathrm{CN}$

(a)

(b)

(c)

Figure 1: (a) Layer of geographic information for water permeability classes $\left(i_{\mathrm{PERM}}\right)$, vegetation density classes $\left(i_{\mathrm{VEG}}\right)$ and drainage capacity classes $\left(i_{\text {SLOPE }}\right)$; (b) layer overlay; (c) CN parameter map.

\subsection{HRU delineation approaches based on $\mathrm{CN}$ classes}

5 The above procedure provides a detailed representation of the spatial heterogeneity of physiographic characteristics of a river basin, in terms of CN-parameter classes. Specifically, considering only integer values for $i_{\mathrm{PERM}}, i_{\mathrm{VEG}}$ and $i_{\mathrm{SLOPE}}$, the number of potential classes is 25 , while further classes can be identified by also allowing intermediate, non-integer values of the three indices. Next, the raster layer of CNs can be used for delineating HRUs, under the assumption that cells with identical $\mathrm{CN}$ values exhibit similar hydrological behavior. In this respect, HRUs can be configured as clusters of such cells, to be

10 represented by the same response model, and thus the total number of model parameters becomes directly proportional to the number of $\mathrm{CN}$-classes across the river basin.

However, such a detailed configuration is not always practical, since it commonly results in a quite large number of HRUs and, consequently, an even larger number of parameters. An obvious way to reduce the number of parameters is through aggregation of the initially formulated HRUs, by considering sub-sets of CNs instead of individual classes. In that case, a

15 representative (e.g., weighted-average) value of the $\mathrm{CN}$-number is obtained, based on the area that each $\mathrm{CN}$-class occupies. Evidently, the parameterization becomes now more flexible but also more subjective, as the model user has to identify the desirable number of aggregated $\mathrm{CN}$-classes, on the one hand, and the associated ranges of $\mathrm{CN}$ values, on the other. 
Hydrol. Earth Syst. Sci. Discuss., doi:10.5194/hess-2016-627, 2016

It is already mentioned that the configuration of HRUs within distributed models is subject to the classical conflict between accuracy in the representation of process heterogeneity, which dictates the required number of HRUs, and model parsimony, which is associated with the number of parameters that are inferred through calibration (Efstratiadis and Koutsoyiannis, 2010). In the case of lumped conceptual schemes, the typical assumption is that only up to five or six parameters can be

5 identified from observed streamflow data (Jakeman and Hornberger, 1993; Wagener et al., 2001). This makes essential to associate the allowable number of HRUs with the available discharge information across the river basin. As a general principle in the HRU configuration procedure, it is proposed that the number of HRUs equals the number of discharge monitoring stations (provided, obviously, that both the quantity and quality of hydrometric data are satisfactory). Therefore, if $N$ discharge monitoring stations are available, then up to $N \mathrm{CN}$ parameter classes should be considered, in order to

10 formulate the corresponding HRU classes. If, for example, only a couple of discharge time series are available at two monitoring stations across the watershed, then only two HRUs should be delineated (see example of Figure 2, illustrating the delineation of two HRUs by using $\mathrm{CN}=63$ as threshold).

In general, the proposed parameterization results in different combinations of the areas covered by the associated HRUs upstream of each station, thus allowing to implicitly accounting for the heterogeneity of catchment characteristics. The calibration of the $N$ sets of model parameters (i.e. one per each HRU) is based on the combined hydrological information embedded in the observed flow data by the $N$ stations. Ideally, these data should be as little correlated as possible, to ensure maximization of the available information. We note that this is far from classical approaches of semi-distributed modelling, where different parameters are assigned to the entire sub-watershed area upstream of each flow monitoring station. If such an area is highly heterogeneous, the resulting parameter values will reflect totally different hydrological behaviors, thus

20 losing their physical interpretation. In contrast, the $\mathrm{CN}$-based approach presupposes that the parameter values of a given HRU represent a specific hydrological behavior, which is quantified in terms of the representative (e.g. spatially averaged) value of the associated $\mathrm{CN}$-class. Hence, through a proper classification of $\mathrm{CNs}$, the user can determine a priori a reasonable (i.e. physically-consistent) and relatively narrow range of feasible parameter bounds, which is of key importance towards ensuring effective and efficient calibrations (Efstratiadis and Koutsoyiannis, 2010).

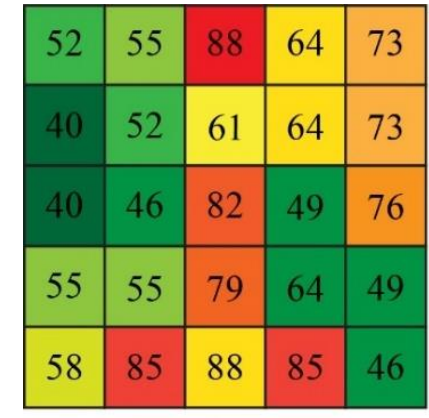

(a)

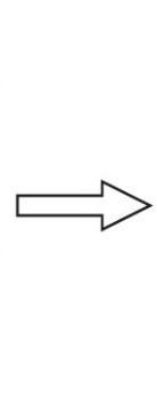

25

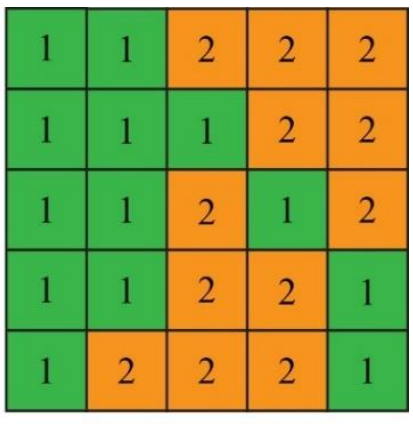

(b)

Figure 2: HRU delineation procedure based on the CN parameter map: (a) CN parameter classes, and (b) configuration of two HRUs, using $\mathrm{CN}=63$ as threshold to determine the associated $\mathrm{CN}$-classes. 
Hydrol. Earth Syst. Sci. Discuss., doi:10.5194/hess-2016-627, 2016

\section{Case Study}

The proposed method is tested in the context of HYDROGEIOS model, the parameterization of which is based on the HRU concept. Taking as study area the Nedontas river basin, we investigate and compare alternative HRU configuration approaches and their impacts on model calibration and associated predictive capacity.

\section{$5 \quad 5.1$ HYDROGEIOS modelling framework}

The modelling framework is based on the recently upgraded version of HYDROGEIOS software, which is a GIS-based tool implementing conjunctive simulation of surface and groundwater processes across river basins that may also be humanmodified; in that case, the allocation of hydrological fluxes under anthropogenic interventions are represented through a system-oriented water management scheme. While the software was initially developed for monthly simulations (Efstratiadis

10 et al., 2008; Nalbantis et al., 2011), it has been upgraded to also support daily and hourly time steps, in order to represent fine-scale hydrological processes (particularly floods) across river basins (Efstratiadis et al., 2014c).

The water fluxes across the surface hydrological system are represented on the basis of a semi-distributed schematization of the river basin, which is divided into sub-basins that are interconnected through the hydrographic network. The network propagates surface runoff from sub-basins, where precipitation and potential evapotranspiration (PET) time series are

15 assigned as hydrological stresses. The model parameterization is based on the HRU concept, thus the surface hydrological processes and associated model parameters are considered homogeneous within each HRU. At each basin partition, i.e. the intersection of sub-basin and HRU, a conceptual precipitation-runoff model is employed, transforming precipitation into actual evapotranspiration, percolation to the groundwater system and surface runoff over the sub-basin. A schematic layout of the modelling components and associated fluxes is shown in Fig. 3. The model comprises three conceptual storage

20 mechanisms: (a) an interception tank, on the ground, which transforms precipitation into direct evaporation, overland flow and infiltration, using two parameters, i.e. interception capacity and maximum infiltration rate; (b) an upper soil moisture accounting tank, which receives infiltration and produces evapotranspiration through the upper soil, excess runoff due to soil saturation, horizontal flow through the soil (interflow), and vertical flow to the deeper zone, considered as constant ratio of infiltration; this component uses four parameters, i.e., field capacity, threshold up to interflow, recession rate for interflow, and percentage of infiltration; (c) a lower soil moisture accounting tank, which receives vertical flow from the upper tank to produce deep evapotranspiration and percolation to the saturated zone (represented by the groundwater model), using a sole parameter, i.e. the recession rate for percolation. Totally, seven parameters are assigned to each HRU, while an additional parameter is considered for each sub-basin, by means of recession rate of a linear reservoir routing scheme; the latter is employed to propagate the runoff produced across each sub-basin (i.e. the aggregated runoff from all common HRU

30 partitions) to its outlet. Water losses along the river network are modelled by assigning infiltration parameters to particular reaches, which represent constant ratios of discharge that are conducted to the groundwater system. 
Hydrol. Earth Syst. Sci. Discuss., doi:10.5194/hess-2016-627, 2016

Manuscript under review for journal Hydrol. Earth Syst. Sci.

Published: 6 December 2016

(c) Author(s) 2016. CC-BY 3.0 License.

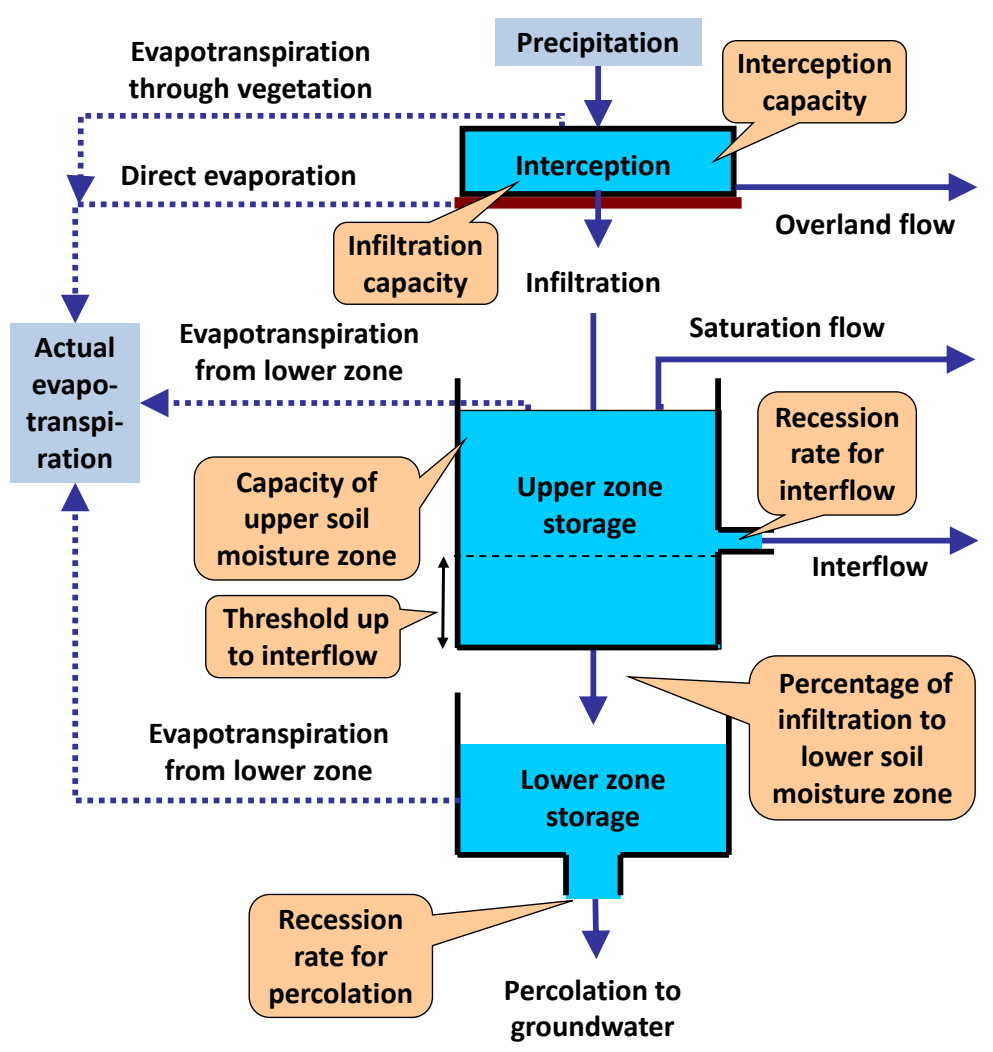

Figure 3: Representation of modelling components and associated fluxes within basin partitions. Model inputs, i.e. precipitation and PET, vary across sub-basins, while model parameters, shown in callouts, vary across HRUs.

Groundwater processes are represented through a multi-cell approach, where the aquifer is resolved into non-rectangular

cells that formulate a network of conceptual tanks and associated flow elements. It has been proven that this approach allows the description of complex geometries based on the physical characteristics of the groundwater system, through parsimonious structures (Rozos and Koutsoyiannis, 2006). Two parameters are assigned per groundwater cell, representing their key hydraulic properties, i.e. conductivity and specific yield. Distributed stresses, namely inflows due to infiltration underneath each river segment, areal inflows due to percolation and abstractions due to pumping, are propagated across the groundwater network, outputs of which are point outflows to the river network through springs (baseflow) and underground losses to neighbouring basins or the sea.

For given nodal inflows, i.e. surface and groundwater runoff, the allocation of hydrological fluxes across the river network is expressed in terms of a graph optimization problem, to account for human interventions, i.e. surface and groundwater abstractions, as well as losses due to infiltration (Efstratiadis et al., 2008; Nalbantis et al., 2011). In hourly simulations,

15 routing phenomena are also represented, by re-solving the problem from upstream to downstream. In the case of relatively steep channels, a kinematic-wave model is employed, implementing a temporal transfer of the hydrograph from the upstream 
Hydrol. Earth Syst. Sci. Discuss., doi:10.5194/hess-2016-627, 2016

Manuscript under review for journal Hydrol. Earth Syst. Sci.

Published: 6 December 2016

(c) Author(s) 2016. CC-BY 3.0 License.

to the downstream node, while in the case of mild slopes, a Muskingum diffusive-wave scheme is employed, implementing a non-linear transformation of the input hydrograph (Koussis, 2009, 2010).

The conjunctive model, in its general form, comprises seven parameters per HRU, one parameter per sub-basin, one parameter per river segment and two parameters per groundwater cell. In order to reduce the number of parameters,

5 especially for the groundwater processes, for which it is often difficult to gather detailed spatial information (e.g. piezometric data), it is recommended to group cells with common hydraulic properties. For the automatic estimation of the unknown model parameters, an advanced calibration module is embedded that provides a set of statistical and empirical criteria for model fitting to multiple responses, such as river and spring discharge, and for several options concerning the definition of the feasible search space. These criteria include: (a) typical statistical metrics, such as efficiency and bias, aiming to ensure

10 as close fit as possible of the simulated hydrographs against the observed ones; (b) zero-flow penalties, emphasizing flow intermittencies that are easily observable, and very important from a water management perspective; and (c) trend penalties, to prohibit generating unrealistic flow or groundwater level patterns, in case of non-observable model variables. In the last version of HYDROGEIOS, it has also been introduced a modified efficiency index, which accounts for flow values above the observed mean, thus forcing fitting to flood fluxes. According to the available information, the user may use multiple

15 criteria aggregated in a weighted objective function. The objective function and the parameter bounds are inputs to a complex calibration problem, which is handled through the advanced global optimization technique of the evolutionary annealing-simplex algorithm (Efstratiadis and Koutsoyiannis, 2002; Rozos et al., 2004; Tsoukalas et al., 2016).

\subsection{Study area and data}

The study area is the Nedontas river basin, upstream of the monitoring station "Latomeio (quarry) Baka", which is located in

20 the southeastern part of Peloponnesus, Greece and drains into the Gulf of Messenia (Fig. 4). The basin is surrounded by Taygetos mountain and has a drainage area of $118.4 \mathrm{~km}^{2}$ and an average elevation of $770 \mathrm{~m}$, reaching a maximum elevation of $1715 \mathrm{~m}$ and a minimum of $93 \mathrm{~m}$ at the basin outlet. Terrain slope ranges from almost flat on the lowland and riverside areas to $76 \%$ on the steep mountain slopes, with the mean slope calculated at $22 \%$. The Nedontas River originates in the western slopes of Taygetos and is mainly formed by three tributaries: its headwaters comprise the Nedousa and Alagonia

25 tributaries as well as spring flows in their sub-basins; the upper reach of Nedontas is joined by the lower reach of Karveliotis stream emanating from the SE area of the basin. The length of the main river course is about $26 \mathrm{~km}$; the river discharges in the Gulf of Messenia, traversing the city of Kalamata, a regional economic center of southwest Peloponnese with a population of 55000 inhabitants.

The broader area is characterized by a mild Mediterranean climate influenced by orography, with long dry summers from

30 April to October and wet winters from November to March. Mean annual temperature range from $13{ }^{\circ} \mathrm{C}$ to $19{ }^{\circ} \mathrm{C}$, with July being the hottest month $\left(26.4^{\circ} \mathrm{C}\right)$ and January the coldest $\left(10.2^{\circ} \mathrm{C}\right)$. Mean annual precipitation varies from $600 \mathrm{~mm}$ at the south, $1500 \mathrm{~mm}$ on the mountain range and $800-1200 \mathrm{~mm}$ in the central and northern plains and hilly areas. Nedontas 
Hydrol. Earth Syst. Sci. Discuss., doi:10.5194/hess-2016-627, 2016

Manuscript under review for journal Hydrol. Earth Syst. Sci.

Published: 6 December 2016

(c) Author(s) 2016. CC-BY 3.0 License.
Hydrology and

Earth System

Sciences

Discussions

(c) $\underset{\mathrm{BY}}{(i)}$

discharge is characterized by significant seasonal variability, since during the dry period the flow is occasionally interrupted. On a mean annual basis, the runoff arriving at the outlet is approximately $550 \mathrm{~mm}$ (mean discharge $2.1 \mathrm{~m}^{3} / \mathrm{s}$ ).

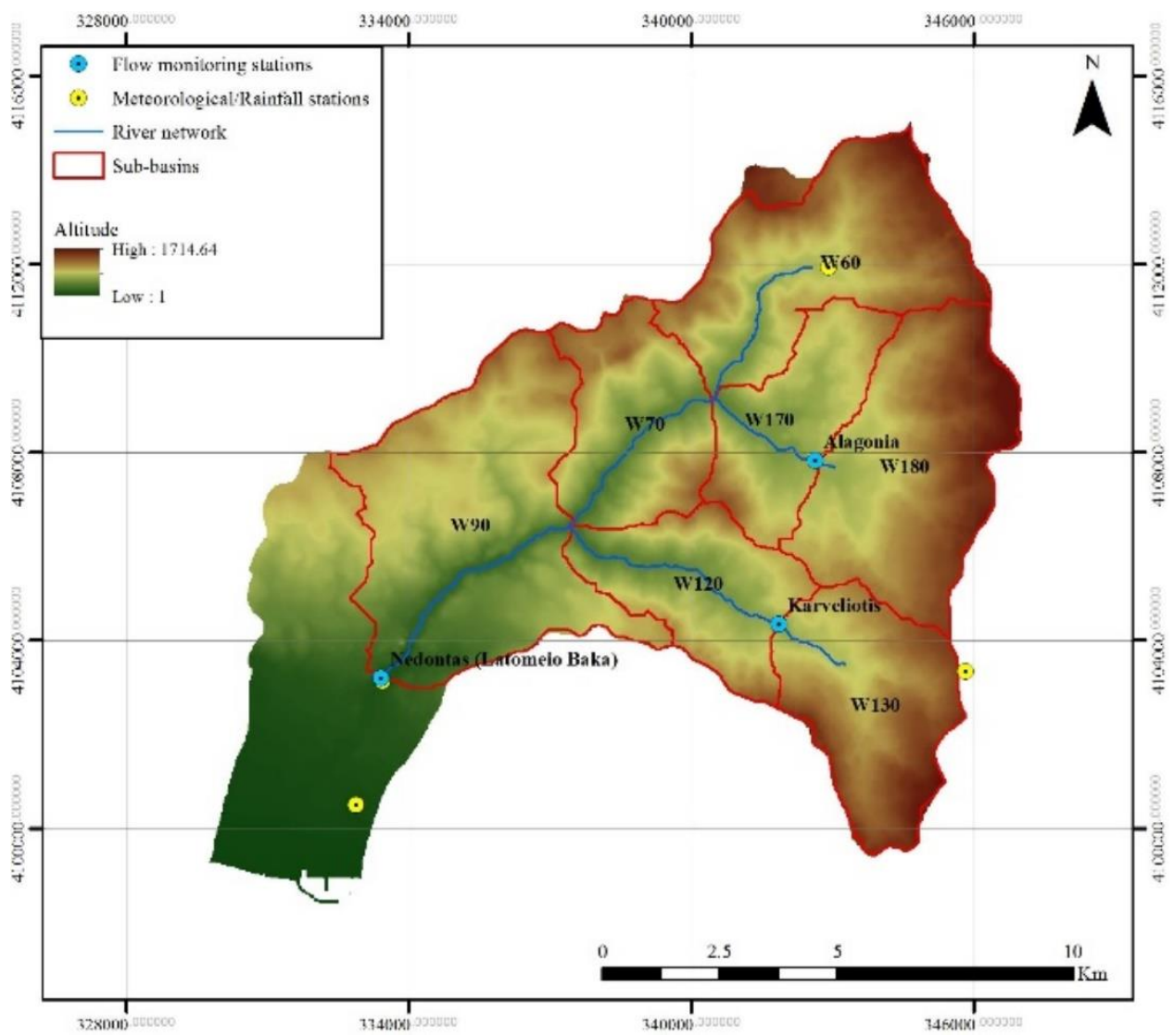

Figure 4: Digital map of Nedontas river basin, also showing monitoring stations (meteorological and hydrometric) and main modelling components (sub-basins, reaches).

In the context of a recent research project (DEUCALION: Assessment of flood flows in Greece under conditions of hydroclimatic variability: Development of physically-established conceptual-probabilistic framework and computational tools; 2011-2014), the river basin was equipped with a telemetry-based hydro-meteorological network, comprising four meteorological and three flow-gauging stations, installed at the basin outlet (Latomeio Baka) and upstream of the two main tributaries, Alagonia and Karveliotis (Efstratiadis et al., 2013). In this study, we used raw meteorological and hydrometric data for a three-year period (September 2011 to April 2014), provided at 10 and 15 min intervals, respectively.

For the preparation of input geographical layers, we used a $25 \mathrm{~m}$ resolution DEM, to delineate the river network and associated sub-basins, and to calculate their geometrical properties. In particular, the study area was divided in seven subbasins, by setting a flow accumulation threshold of $10 \mathrm{~km}^{2}$ and by setting additional nodes at the three flow station sites, as

15 illustrated in Fig. 4. The main properties of the sub-basins are summarized in Table 2. Spatially-averaged hydrological inputs, i.e. hourly precipitation and PET time series, were extracted at the sub-basin scale, using the Thiessen polygon 
Hydrol. Earth Syst. Sci. Discuss., doi:10.5194/hess-2016-627, 2016

Manuscript under review for journal Hydrol. Earth Syst. Sci.

Published: 6 December 2016

(c) Author(s) 2016. CC-BY 3.0 License.

method and a semi-empirical radiation-based approach, respectively, that has been recently fitted to local Penman-Monteith data (Tegos et al., 2013). Finally, hourly discharge time series were constructed based on raw hydrometric data, i.e. 15-min interval river stage observations and sparse flow measurements that were used to construct rating curves at the three stations.

Table 2: Sub-basins properties.

\begin{tabular}{cccccc}
\hline Sub-basin & Name & Area $\left(\mathrm{km}^{2}\right)$ & Mean elevation $(\mathrm{m})$ & Stream length $(\mathrm{m})$ & Mean slope $(\%)$ \\
\hline W60 & Nedousa & 19.47 & 1008.9 & 4296.3 & 23.06 \\
W180 & Alagonia & 20.72 & 1092.4 & 497.5 & 18.26 \\
W130 & Karveliotis & 14.92 & 1096.5 & 1721 & 21.17 \\
W170 & Downstream of Alagonia & 10.91 & 739.4 & 2807.4 & 20.26 \\
W120 & Downstream of Karveliotis & 11.81 & 710.1 & 5755.2 & 25.87 \\
W70 & Downstream of Nedousa & 12.53 & 741.9 & 4588.8 & 26.97 \\
W90 & Latomeio Baka & 28.02 & 654.8 & 5920.9 & 18.41 \\
\hline
\end{tabular}

For the delineation of HRUs, distributed geographical data were used, by means of classified geological formations and land cover maps, as well as the raster map of terrain slopes, which are illustrated in Figs. 5a, 5b and 5c, respectively. Specifically: Geological formations and information on the tectonic and lithological elements of the Nedontas River Basin were extracted from geological maps, published by the Institute of Geology \& Mineral Exploration of Greece. As shown in Fig. 5a, the

10 basin includes two major geological formations, i.e. Tripolis geotectonic units, on the western part, and Phyllite-Quartzite series, on the eastern. The Tripolis formations, which occupy the largest part of the hilly and lowland areas of the basin, consist mainly of limestones and marbles, alternating with crystalline slate. Limestone is porous and through the centuries rain and snow water have caused erosion, forming caves with stalagmites, stalactites and other karst landforms. Therefore, waters that have penetrated the permeable and karstified rocks either form springs in many places in the mountainous areas

15 or find their way to the sea as underwater estuaries called "Anavoli". On the other hand, the Phyllite-Quartzite series are extended over the mountain areas (Taygetos) and consists of Permian - Lower Triassic rocks that are characterized by low to moderate permeability. The other three formations occupy only a small area in the SE part of the basin. In particular, Pindos formation consists of Upper Cretaceous - Paleocene rocks, Tyros layers consist of Carboniferous - Upper Triassic rocks, while the Postalpine sediments consist of Quaternary, Holocene and Pliocene rocks.

20 Land-cover classes, illustrated in Fig. 5b, were derived from the CORINE Land Cover 2000 map (CLC2000) produced by the European Environmental Agency. These include broad-leaved forest (37\%), coniferous forest (23\%), transitional woodland-shrub (16\%), pastures (10\%), sclerophyllous vegetation (7\%), mixed forest (3\%), land principally occupied by agriculture, with significant areas of natural vegetation $(3 \%)$, olive groves $(<1 \%)$, complex cultivation patterns $(<1 \%)$, and industrial or commercial units $(<1 \%)$. In general, vegetation favors interception and infiltration against overland flow, thus resulting in smoother flood hydrographs. 
Hydrol. Earth Syst. Sci. Discuss., doi:10.5194/hess-2016-627, 2016

Manuscript under review for journal Hydrol. Earth Syst. Sci.

Published: 6 December 2016

(c) Author(s) 2016. CC-BY 3.0 License.

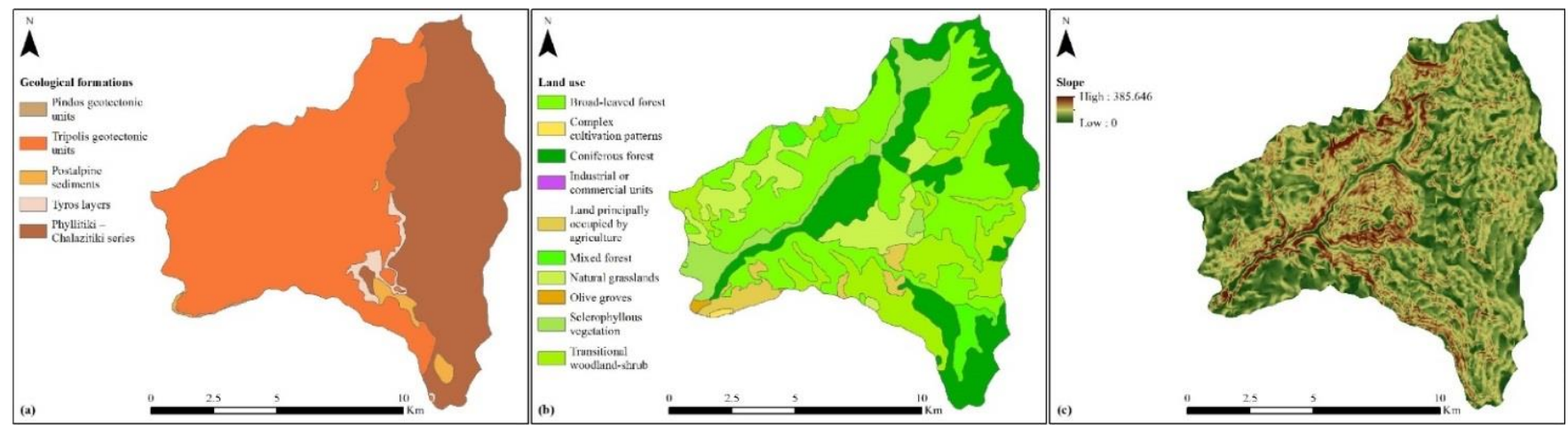

Figure 5: (a) Water permeability classes; (b) land cover classes; (c) terrain slope (\%) classes.

\subsection{Parameterization approaches and HRUs delineation}

Based on the soil, land cover and terrain slope information, we developed three parameterizations of the surface hydrological

system, based on alternative HRU delineation methodologies: unique combination, union of layers, and the proposed $\mathrm{CN}-$ based approach.

In the unique combination delineation methodology, which is based on aggregation using user-defined thresholds for land use, soil type and slope range within each sub-watershed, followed by a spatial overlay scheme, $20 \%, 10 \%$ and $20 \%$ thresholds were used for land use, soil and slope, respectively (Winchell et al., 2013). This means that any land use, soil and

10 slope occupying less than or equal to the area percentage threshold defined in each sub-basin will be lumped with the adjacent dominant cells. A spatial overlay was then performed and cells having the same combination of land use, soil and slope categories were given a unique HRU combination number, resulting in 31 HRUs (Fig. 7a).

In the union of layers delineation methodology, HRUs are defined as the product of separate partitions accounting for different watershed properties. We considered the product of the two dominant geological formations, corresponding to low and high permeability, and the two dominant land uses, corresponding to forests and meadow-pastures, thus obtaining four HRUs (Fig. 7b).

In the proposed $\mathrm{CN}$ approach, the HRU delineation is based on the $\mathrm{CN}$-parameter map of the river basin area, which is automatically produced by overlaying the raster maps of $i_{\mathrm{PERM}}, i_{\mathrm{VEG}}$, and $i_{\mathrm{SLOPE}}$ (Figs. S1a, S1b and S1c respectively), through Eq. (1). The values of the three indices were assigned according to the classification of Table 1, accounting for the dominant classes of permeability, vegetation and drainage capacity of the river basin that were estimated on the basis of geological formation, land use and terrain slope information, respectively (Fig. 5). Initially, a raster map of 18 classes of CN values was created (Fig. 6a), ranging from $\mathrm{CN}=37$, for areas with high permeability, dense vegetation and negligible drainage capacity, to $\mathrm{CN}=91$, for bare areas with low permeability and very high drainage capacity. Next, following the recommended general rule, that the number of HRUs should be equal to the number of discharge monitoring stations in the basin, we formulated three HRUs, based on the quantile classification method where each class contains equal number of 
Hydrol. Earth Syst. Sci. Discuss., doi:10.5194/hess-2016-627, 2016

Manuscript under review for journal Hydrol. Earth Syst. Sci.

Published: 6 December 2016

(c) Author(s) 2016. CC-BY 3.0 License.

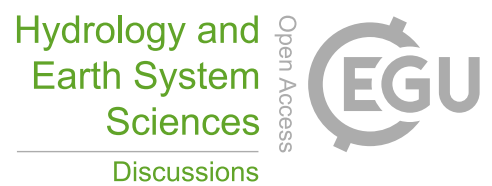

(c) (i)

features. The thresholds used were $\mathrm{CN}=60$ and $\mathrm{CN}=70$ (Fig. 6b), based on which three corresponding HRU classes were delineated (Fig. 7c).

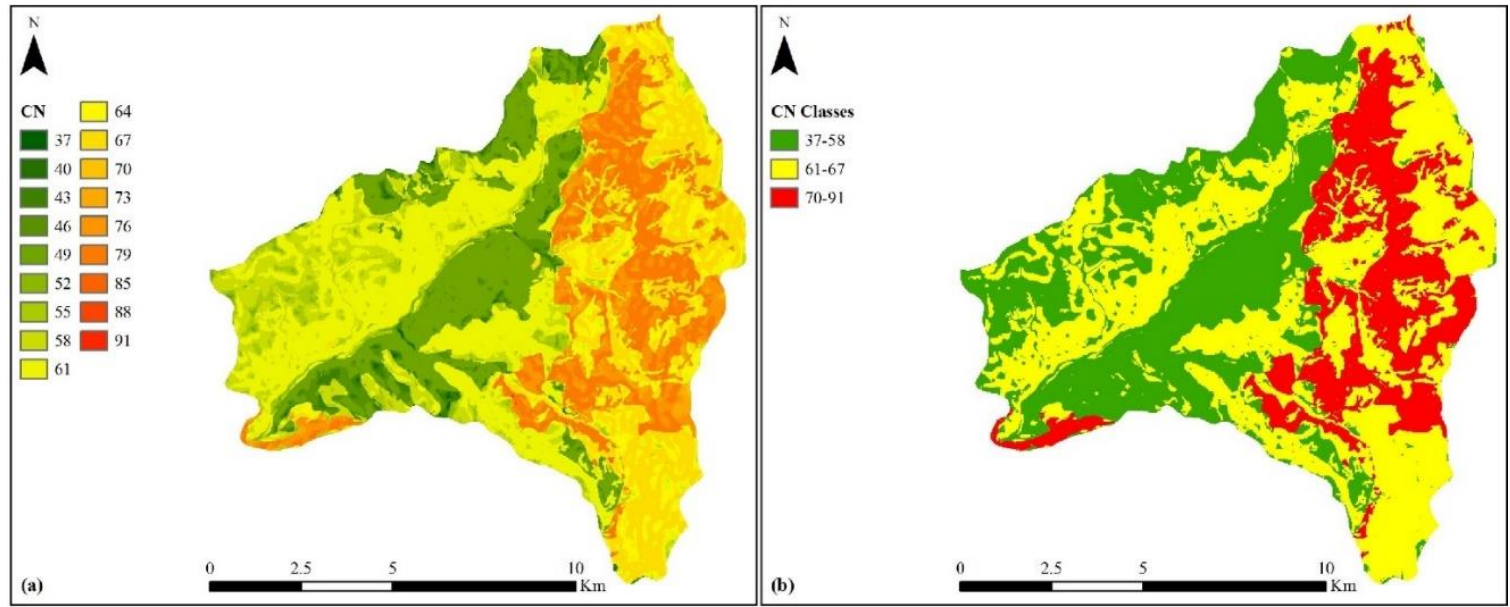

Figure 6: CN parameter map of the Nedontas river basin (a) initial map of $34 \mathrm{CN}$ classes; (b) condensed map of three CN classes,

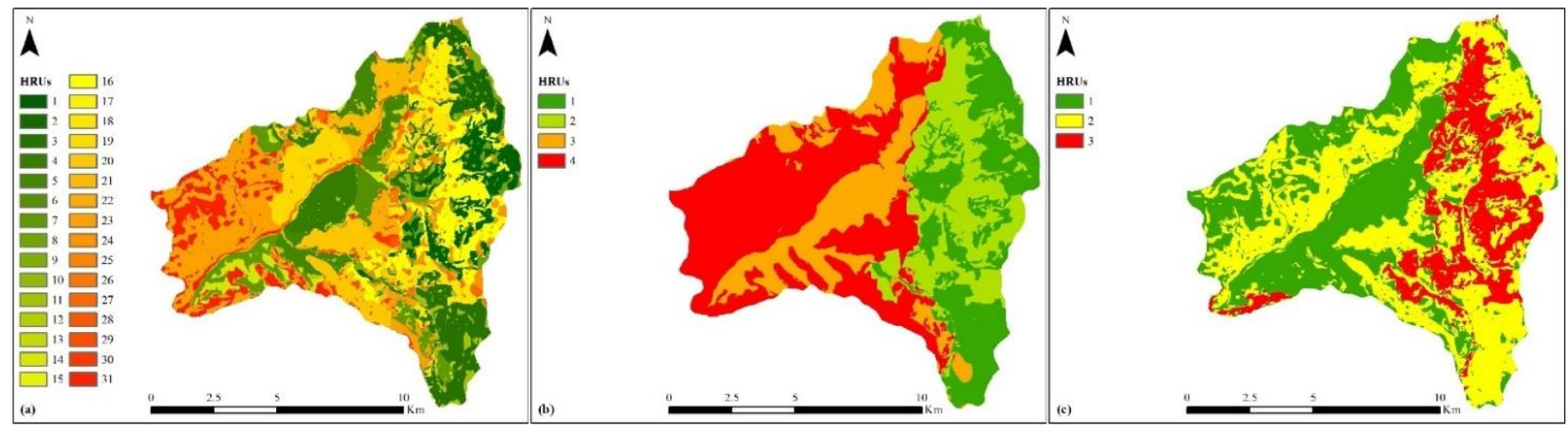

Figure 7: HRU delineation of Nedontas river basin (a) SWAT GIS overlay and threshold definition method - 31 HRUs; (b) HYDROGEIOS Union of Layers method - 4 HRUs; (c) CN approach - 3 HRUs.

\subsection{Model calibration}

10 Based on the three HRU delineations produced by the different methods described above, three different simulation modes were set up in the HYDROGEIOS framework for Nedontas river basin. Along with distributed geographical information for HRU delineation, vector data such as nodes and river network segments, sub-basins, groundwater cells and conduits, and springs were also added to each of the model simulation modes. The hourly precipitation and evapotranspiration input series, initial conditions and settings were kept the same in all simulations, which were performed with an hourly time step for an

15 almost 3-year time period (September 2011 - April 2014). The control period was split in a 10-month calibration period (September 2011 - June 2012) and a 22-month validation period (July 2013 - April 2014). With the simulations 
Hydrol. Earth Syst. Sci. Discuss., doi:10.5194/hess-2016-627, 2016

commencing in September, i.e. before the beginning of the wet season, negligible initial soil moisture was assumed in the upper and lower soil moisture tanks.

The model parameters for hourly simulations were assigned as follows: (a) seven parameters for the rainfall-runoff component of each HRU; (b) one recession parameter for each sub-basin; (c) one hydraulic conductivity and one specific

5 yield parameter for each groundwater cell; and (d) a single leakage coefficient assigned to the downstream river segment accumulating the runoff losses due to infiltration, while a zero value was set for the rest of the segments. Moreover, the specific yield parameter was set to $10 \%$ for all groundwater cells.

Due to the different HRU delineations that were used for each simulation mode, the number of model parameters varied greatly, as shown in Table 3. For the simulation mode with the unique combination HRU delineation $217(31 \times 7) \mathrm{HRU}$

10 parameters were assigned (257 in total), for the mode with the union of layers delineation $28(4 \times 7)$ HRU parameters were assigned (68 in total), and for the mode with the $\mathrm{CN}$ approach $21(3 \times 7) \mathrm{HRU}$ parameters were assigned (61 in total) (Table 3 ). We remark that for the parameters of the groundwater system and the sub-basins (40, in total), we only provided rough estimations, to ensure realistic fluctuations of the associated fluxes. In fact, most of parameters were grouped into clusters (two recession rates for sub-basins, common specific yield for all groundwater cells), thus the actual number of unknown

15 control variables of the optimization problem was much smaller.

For each simulation mode, the unknown model parameters were calibrated against hourly time series of observed discharge at the Karveliotis, Alagonia and Latomeio Baka (basin outlet) monitoring stations. For the calibration of the above model parameters the coefficient of efficiency or Nash-Sutcliffe index (Nash and Sutcliffe, 1970) was used, as well as a variation of it, calculated only for the observed and simulated flow values that are above the mean value of the observed time series, in

20 order to preserve the high flows of the hydrograph. As already mentioned, this is a very important aspect in fine time scale simulations, aiming to reproduce the observed floods and their peaks. Finally, a trend penalty was used to control the generation of unreasonable trends in the groundwater level behavior, based on the Mann-Kendall rank correlation test (Kottegoda, 1980, p. 32-34).

Parameter optimization was carried out by employing a hybrid strategy, combing human experience and automatic tools

25 (Boyle et al., 2000; Mazi et al., 2004a, 2004b; Rozos et al., 2004), aiming towards a realistic set of parameters that would ensure satisfactory predictive capacity for all model responses. A similar strategy was used for all three models, through progressive improvements of a relatively small group of parameters; however, the time and effort spent for optimizing each model differed markedly. A 'rough' calibration was initially employed that allowed large parameter variations; several optimization runs were carried out by modifying the bounds of the feasible parameter search space, while trying different 30 combinations of criteria weights. The calibration was then focused on the optimization of the HRU parameters as well as on the most significant groundwater parameters, in order to attain a good fit of the hydrograph at the basin outlet, especially during high flows, and a satisfactory fit of the spring discharges. Once a relatively good solution was achieved, the calibration focused on the improvement of specific aspects of the model responses, while ensuring a realistic water balance of the basin. 
Hydrol. Earth Syst. Sci. Discuss., doi:10.5194/hess-2016-627, 2016

Table 3. Number of HRUs and their parameters resulted from each delineation approach.

\begin{tabular}{rccc}
\hline & Unique Combination & Union of Layers & CN approach \\
\hline No. of HRUs & 31 & 4 & 3 \\
No. of HRU parameters & 217 & 28 & 21 \\
Total No. of parameters & 257 & 68 & 61 \\
Optimization effort* & $\sim 3$ & $\sim 1.5$ & 1 \\
\hline
\end{tabular}

* Ranging from one to five, where 1 indicates minor and 5 major optimization effort.

\section{Results and Discussion}

Theoretically, as the number of parameters increases, one should expect obtaining better calibration results, i.e. closer fitting

5 to the observed data. However, in practice, the increase of model parameters induces more complexity to the calibration problem, which is far from a straightforward optimization task. In fact, as a result of interrelated uncertainties and errors in all aspects of hydrological modelling and calibration (Efstratiadis and Koutsoyiannis, 2010), the outcome of automatic optimization procedures may be a model of poor predictive capacity, typically because of algorithmic weaknesses (e.g., trapping to local optima). In this context, it was not surprising that in the specific study, the optimal performance in

10 calibration, and particularly in validation, was achieved by the most parsimonious parameterization, based on the proposed CN approach for HRU delineation.

The optimized statistical measures against the simulated runoffs are summarized in Table 4, whereas Figs. 8-10 compare the observed hydrographs at the three monitoring sites against the ones simulated with the three HRU delineation methods. Regarding the runoff at the basin outlet (Fig. 8), a very good fit is achieved by all three models, for both the calibration and

15 validation periods. Overall, the highest efficiency values are obtained by the simulation mode with the $\mathrm{CN}$ approach for HRU delineation, with $81.4 \%$ and $80.2 \%$ for the calibration and validation periods, respectively, compared to $80.1 \%$ and $77.1 \%$ obtained by the simulations performed with the union of layers delineation, and $76.8 \%$ and $71.9 \%$ with the unique combination delineation. As shown in Fig. 8, the simulations preserve the important features of the hydrographs, such as the high flows over the winter and zero flows over the summer periods for the calibration periods. Although the high flow efficiency values are very good for the calibration period, none of the models succeeds to simulate well the flow between March and June 2013, leading to unsatisfactory prediction of high flows during the validation period for the simulations with the unique combination and union of layers approaches and acceptable for the simulation with the CN-based approach. This is generally a weak point of the Nedontas river basin model. Both modes with $\mathrm{CN}$ approach and unique combination HRU delineations simulate well the low flows, but the simulation mode with union of layers delineation overestimates the low

25 summer flow both for the calibration and the validation periods.

For the Alagonia monitoring station (Fig. 9), located in the NE part of the basin, the efficiency values, although lower, were still very satisfactory, with $79.7 \%$ in calibration and $75.3 \%$ in validation for the simulation with the CN approach for the HRU delineation, $75.4 \%$ and $68.0 \%$ respectively with the unique combination delineation, and $65.8 \%$ and $72.6 \%$ 
Hydrol. Earth Syst. Sci. Discuss., doi:10.5194/hess-2016-627, 2016

Manuscript under review for journal Hydrol. Earth Syst. Sci.

Published: 6 December 2016

(C) Author(s) 2016. CC-BY 3.0 License.
Hydrology and

Earth System

Sciences

Discussions

(c) (i)

respectively with the union of layers delineation. High flow efficiency was satisfactory for the calibration period and for the validation period only with the simulation with the $\mathrm{CN}$ approach for HRU delineation; the other two simulation modes produced mixed results. The modes with the $\mathrm{CN}$ approach and unique combination delineations simulated better the high flows in the calibration period, while all modes simulated well the low summer flows.

5 The best efficiency performance by all three simulation modes was achieved for the Karveliotis monitoring station (Fig. 9), located in the eastern part of the basin (calibration value first, validation value second): $89.2 \%$ and $83.7 \%$ for simulation with the $\mathrm{CN}$ approach delineation, $90.8 \%$ and $81.3 \%$ for the simulation with the unique combination delineation, and 65.5 $\%$ and $76.2 \%$ for simulation with the union of layers delineation. High flow efficiency was satisfactory both for the calibration and validation periods, with the mode with the $\mathrm{CN}$ approach delineation producing the best results with efficiency

10 values $78.9 \%$ and $57.9 \%$, respectively. Although the models preserved the overall behavior of the hydrographs, some of the high flow events were somewhat underestimated, while the mode with the union of layers delineation also underestimated the summer flows.

Table 4: Optimal values of efficiency, high flow efficiency and average bias for the calibration and validation periods for the simulations modes with (a) unique combination HRU delineation, (b) union of layers HRU delineation, (c) CN approach for HRU

\begin{tabular}{lcccc}
\hline Hourly runoff & \multicolumn{2}{c}{ Calibration period } & \multicolumn{2}{c}{ Validation period } \\
\hline & Efficiency & High Flow Eff. & Efficiency & High Flow Eff. \\
\hline Basin outlet - Latomeio Baka & 0.768 & 0.809 & 0.719 & 0.068 \\
Monitoring station - Karveliotis & 0.908 & 0.663 & 0.813 & 0.580 \\
Monitoring station - Alagonia & 0.754 & 0.253 & 0.680 & 0.141 \\
\hline
\end{tabular}

(a)

\begin{tabular}{lcccc}
\hline Hourly runoff & \multicolumn{2}{c}{ Calibration period } & \multicolumn{2}{c}{ Validation period } \\
\hline Basin outlet - Latomeio Baka & 0.801 & 0.757 & 0.771 & 0.195 \\
Monitoring station - Karveliotis & 0.655 & 0.693 & 0.762 & 0.368 \\
Monitoring station - Alagonia & 0.658 & 0.090 & 0.726 & 0.411 \\
\hline
\end{tabular}

(b)

\begin{tabular}{lcccc}
\hline Hourly runoff & \multicolumn{2}{c}{ Calibration period } & \multicolumn{2}{c}{ Validation period } \\
\hline Basin outlet - Latomeio Baka & 0.814 & 0.816 & 0.802 & 0.241 \\
Monitoring station - Karveliotis & 0.892 & 0.789 & 0.837 & 0.579 \\
Monitoring station - Alagonia & 0.797 & 0.300 & 0.753 & 0.440 \\
\hline
\end{tabular}

(c) 
Hydrol. Earth Syst. Sci. Discuss., doi:10.5194/hess-2016-627, 2016

Manuscript under review for journal Hydrol. Earth Syst. Sci.

Published: 6 December 2016
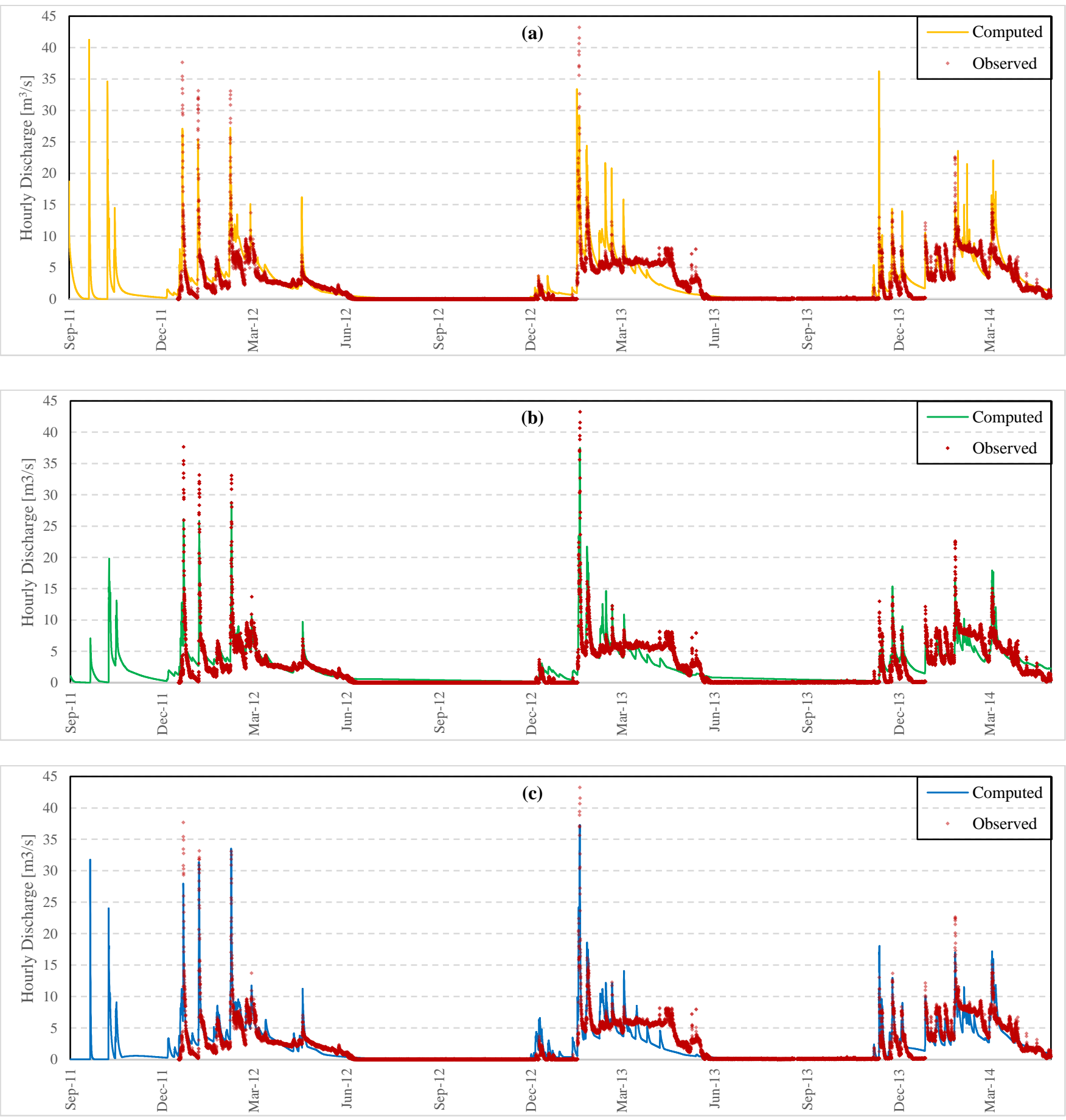

5 Figure 8: Computed vs. observed discharge series at the basin outlet (Latomeio Baka) for the simulations modes with (a) unique combination HRU delineation; (b) union of layers HRU delineation; (c) CN approach for HRU delineation. 
Hydrol. Earth Syst. Sci. Discuss., doi:10.5194/hess-2016-627, 2016

Manuscript under review for journal Hydrol. Earth Syst. Sci.

Published: 6 December 2016

(C) Author(s) 2016. CC-BY 3.0 License.
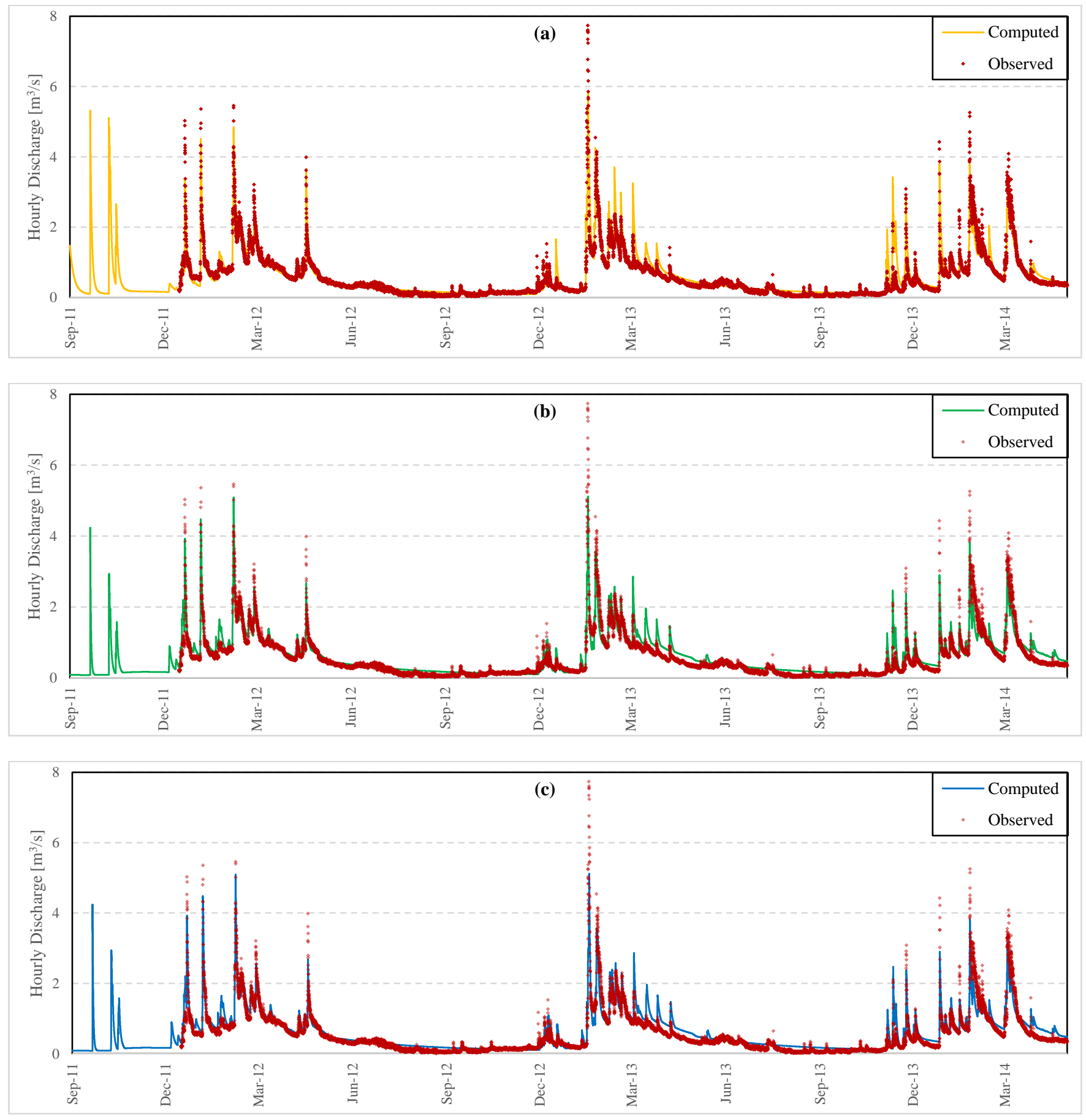

Figure 9: Computed vs. observed discharge series at Karveliotis monitoring station for the simulations modes with (a) unique combination HRU delineation; (b) union of layers HRU delineation; (c) CN approach for HRU delineation. 
Hydrol. Earth Syst. Sci. Discuss., doi:10.5194/hess-2016-627, 2016

Manuscript under review for journal Hydrol. Earth Syst. Sci.

Published: 6 December 2016
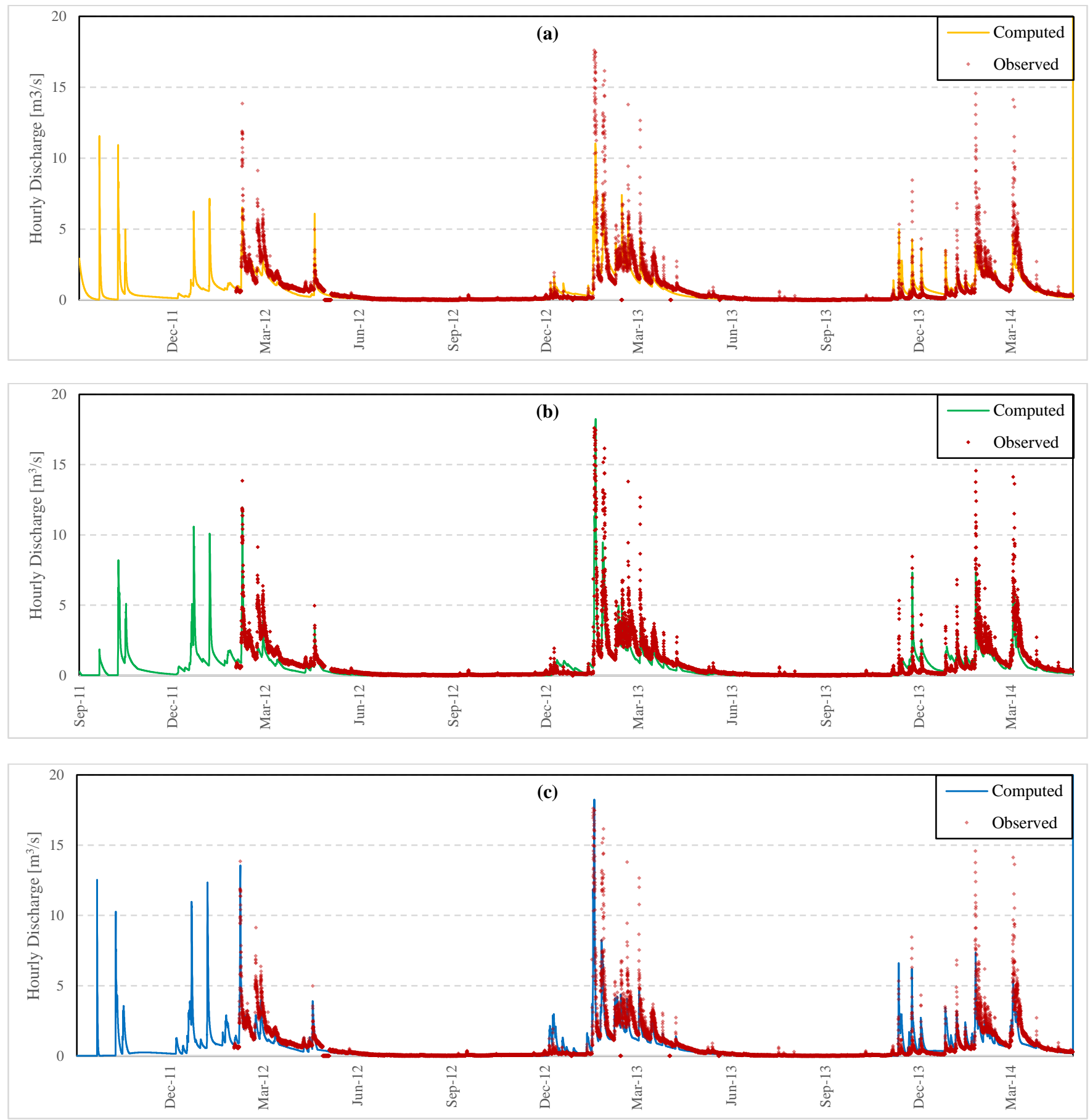

Figure 10: Computed vs. observed discharge series at Alagonia monitoring station for the simulations modes with (a) unique 
Hydrol. Earth Syst. Sci. Discuss., doi:10.5194/hess-2016-627, 2016

Manuscript under review for journal Hydrol. Earth Syst. Sci.

Published: 6 December 2016

(c) Author(s) 2016. CC-BY 3.0 License.

Apart from the performance results obtained in terms of efficiency, an important aspect of this study was to explore the difference between each mode in terms of the time and effort spent for parameter optimization. Table 3 provides a qualitative expression of this effort, which is mainly associated with the time needed for manual interventions within the hybrid calibration procedure, and the number of individual optimizations, using small sub-sets of parameters or different ranges of

5 their feasible bounds, in order to achieve an acceptable model performance, and simultaneously ensuring realistic hydrological behaviours, in terms of water balance components and parameter values. The simulation mode with the unique combination delineation required at least triple the effort to achieve satisfactory performance compared to the simulation modes with the union of layers and $\mathrm{CN}$ approach HRU delineations, while preserving a realistic set of parameters turned out to be a very tedious task.

10 Table 5 shows the optimal values of the seven parameters assigned to the corresponding HRUs, as calibrated for the simulation mode with the $\mathrm{CN}$ approach. A low $\mathrm{CN}$ value indicates areas of the basin with very high water permeability, dense vegetation and very low drainage capacity, which leads to minimum runoff. On the other hand, a high $\mathrm{CN}$ value indicates areas of the basin with very low water permeability, no vegetation and a very high drainage capacity, leading to higher runoff values. Therefore, HRUs with lower $\mathrm{CN}$ value range are expected to produce less surface runoff and more

15 groundwater flow than HRUs with higher $\mathrm{CN}$ value range. Therefore, it is not surprising that the maximum infiltration ratio, which is directly associated with soil permeability properties, is higher for the HRUs with low $\mathrm{CN}$ range and decreases for the HRUs with higher $\mathrm{CN}$ value ranges. On the other hand, the soil capacity seems to be more explained by terrain slope characteristics. Thus, the flat plain areas of the basin have much larger capacities than the mountainous ones. Recession rates for percolation, as well as the percentage of infiltration to the lower zone, are also associated with permeability. Therefore, infiltration rates through the high-permeability soils are significant and their contribution to surface flow is limited.

Table 6 summarizes the mean annual water balance components of the basin for the entire simulation period, ending in April 2014. Significant part of precipitation is lost to evapotranspiration (34.3\%) and to underground runoff (23.2 \%). These values differ by 10-20\% at the end of a hydrologic year (mid-autumn), with increased values of evapotranspiration and decreased values of underground losses. Percolation reaches $35.9 \%$ of precipitation, whereas surface runoff is $22.8 \%$. The mean annual runoff coefficient is estimated to be around $33.0 \%$. 
Hydrol. Earth Syst. Sci. Discuss., doi:10.5194/hess-2016-627, 2016

Manuscript under review for journal Hydrol. Earth Syst. Sci.

Published: 6 December 2016

(c) Author(s) 2016. CC-BY 3.0 License.

Table 5: Calibrated HRU parameters of the simulation with the CN-based HRU delineation.

\begin{tabular}{lccc}
\hline HRU & CN 29-59 & CN 61-69 & CN 73-91 \\
\hline Total Area $\left(\mathrm{km}^{2}\right)$ & 40.2 & 54.8 & 22.9 \\
\hline Max. infiltration ratio (mm/h) & 80.0 & 61.3 & 39.4 \\
Interception capacity (mm) & 50.0 & 39.4 & 5.0 \\
Soil capacity up to spill (mm) & 393.5 & 377.0 & 50.0 \\
Perc. of infiltration to the lower zone (\%) & 78.8 & 54.083 & 5.292 \\
Soil capacity up to interflow (mm) & 500.0 & 428.4 & 110.6 \\
Recession rate for interflow (\%) & 0.426 & 0.231 & 2.571 \\
Recession rate for percolation (\%) & 0.187 & 0.116 & 0.055 \\
\hline
\end{tabular}

Table 6: Simulated water balance of the simulation with the CN-based HRU delineation.

\begin{tabular}{lcc}
\hline Variable & $\begin{array}{c}\text { Mean annual value } \\
(\mathrm{mm})\end{array}$ & $\begin{array}{c}\text { Mean annual value } \\
\left(\mathrm{hm}^{3}\right)\end{array}$ \\
\hline Precipitation & 1690.3 & 200.1 \\
Evapotranspiration & 623.0 & 73.8 \\
Percolation & 607.1 & 71.9 \\
Surface runoff & 385.5 & 45.6 \\
Spring runoff & 249.6 & 29.6 \\
Underground losses & 343.7 & 49.9 \\
Soil storage change & 183.6 & 21.7 \\
Groundwater storage change & 29.3 & 3.5 \\
Outlet runoff & 557.2 & 66.0 \\
\hline
\end{tabular}

\begin{tabular}{lc}
\hline \multicolumn{2}{c}{ Overall Balance } \\
\hline Output variable & $\begin{array}{c}\text { Percentage of } \\
\text { precipitation }(\%)\end{array}$ \\
\hline Evapotranspiration & 34.3 \\
River outflow & 30.7 \\
Underground losses & 23.2 \\
Storage change & 11.7 \\
\hline
\end{tabular}


Hydrol. Earth Syst. Sci. Discuss., doi:10.5194/hess-2016-627, 2016

\section{Summary and Conclusions}

In the context of distributed hydrological modeling, HRU configuration is subject to the conflict between accuracy in the representation of process heterogeneity, dictating the required number of HRUs, and model parsimony, associated with the number of parameters inferred through calibration. To reduce the subjectivity introduced by defining a relatively small number of HRUs in a parsimonious modeling structure, this research provides empirical guidelines for formulating HRUs based on the Curve Number (CN) concept. Key innovations of our research are: (1) the formulation of CN maps, accounting for three major physiographic characteristics of the river basin, and its semi-automatic implementation in GIS environment; (2) the use of these maps as input layer for delineating HRUs within hydrological models of various levels of complexity; (3) the use of the $\mathrm{CN}$ parameter as abstract information for configuring a specified number of HRUs in semi-distributed models, including the updated version of HYDROGEIOS modeling framework.

Specifically, in contrast to the standard SCS-CN method, which recommends CN-values in terms of four soil types and several land use classes, the proposed approach attempts to better represent the physiographic properties of the river basin, by including additional information associated with its hydrological response that accounts in detail for three, instead of two major physiographic characteristics of a drainage basin. These are: (a) soil permeability, based on the mechanical properties

15 of the soil and the unsaturated zone, (b) vegetation density based on the land use/land cover characteristics related to the precipitation retention mechanisms, soil roughness and filtration capacity, and (c) drainage capacity, based on the geomorphological characteristics of the basin (typically terrain slope) and the existence of retention structures across it. The method is implemented semi-automatically in a GIS environment, where the three classified levels of spatial information are overlaid through Eq. (1), to produce a layer of spatially distributed values of the $\mathrm{CN}$ parameter over the area of interest.

20 A raster map of $\mathrm{CN}$ values may have several applications, since this parameter is commonly used in watershed hydrology. For instance, it can provide information on potential maximum soil moisture retention at the grid-scale, since $\mathrm{CN}$ is directly associated with this key property of soils. Another application, emphasized in our research, is the use of CN data as proxy for delineating HRUs in the context of distributed hydrological models. As the level of detail of the model parameterization depends on the number of HRUs, the user can determine a specific number of $\mathrm{CN}$ classes for subsequent use as basis for HRU configuration, through aggregating cells of common $\mathrm{CN}$ classes. We highlighted that model complexity, expressed in terms of number of $\mathrm{CN}$ classes and, consequently, number of HRUs, should be consistent with the available hydrological information. Therefore, our recommendation is to provide as many HRUs as the number of available discharge observation stations in the basin. This approach ensures a satisfactory balance between process realism and model parsimony, and also makes essential to take advantage of all available information in order to avoid over-parameterized schemes.

30 The CN-based approach for HRU delineation is incorporated in the last version of HYDROGEIOS modelling framework, which has been extended to also support continuous simulation at hourly time scales. Although the model was from its origin built upon the HRU concept, the configuration of HRUs was implemented as the Cartesian product of classified layers of physiographic characteristics of the watershed (commonly known as "union of layers"), this resulting in a specific number of 
Hydrol. Earth Syst. Sci. Discuss., doi:10.5194/hess-2016-627, 2016

Manuscript under review for journal Hydrol. Earth Syst. Sci.

Published: 6 December 2016

(c) Author(s) 2016. CC-BY 3.0 License.

HRUs, i.e. the product of different layer classes (in contrast to the CN-based approach, where the number of HRUs is determined a priori). In order to reduce this number, it was essential to assign the same parameter values to HURs with close characteristics, which is a quite subjective decision. The new approach is more objective, more flexible and, ultimately, more parsimonious. Furthermore, it allows explaining the HRU response and associated parameter values in terms of CNs; for instance, it is anticipated that an area with low $\mathrm{CN}$ values will generate less surface runoff than an area of moderate or high CN's. The correspondence of HRU's response with CN is very advantageous, since the user can easily recognize whether the model parameters are physically consistent or not, and, consequently, evaluate the model robustness not only in terms of goodness-of-fit in validation, but also according to its physical grounds.

The new $\mathrm{CN}$-approach for HRU delineation was demonstrated in the hydrological simulation of Nedontas river basin,

10 Greece, where parameterizations of different levels of complexity were employed within the HYDROGEIOS modelling framework. The $\mathrm{CN}$-approach was tested and compared against alternative $\mathrm{HRU}$ configuration approaches (i.e. unique combination and union of layers) and their impacts on model calibration and associated predictive capacity. Results showed that the optimal performance in calibration and particularly in validation, was achieved by the most parsimonious parameterisation, i.e. the $\mathrm{CN}$ approach. While better calibration results are usually expected with the increase of model

15 parameters, in practice, however, this increase introduces further complexity to the calibration problem, inherently suffering from multiple uncertainties and errors within all aspects of the calibration procedure. In fact, the calibration effort (in terms of time needed for manual interventions, as well as number of individual optimisations considering sub-sets of parameters), for achieving an acceptable model performance while simultaneously ensuring realistic hydrological behaviour, varied markedly with the different HRU configuration approaches. Once again, more parameters proved a weakness, as they

20 escalated the effort required for parameter optimization. Finally, as expected, the $\mathrm{CN}$ approach achieved optimal values of the HRU parameters in agreement with their physical interpretation representing a specific hydrological behavior (e.g., HRUs with high $\mathrm{CN}$-values produce most of the runoff) that is quantified in terms of the representative value of the associated CN-class. Hence, through a proper classification of $\mathrm{CNs}$, the user can determine a priori a reasonable and relatively narrow range of feasible parameter bounds, which is of key importance towards ensuring effective and efficient calibrations.

Future research steps involve testing this approach in a representative number of river basins, as well as its implementation within different modelling schemes.

\section{Acknowledgments}

The research paper is funded by Cyprus University of Technology Open Access Author Fund. 
Hydrol. Earth Syst. Sci. Discuss., doi:10.5194/hess-2016-627, 2016

Manuscript under review for journal Hydrol. Earth Syst. Sci.

Published: 6 December 2016

(c) Author(s) 2016. CC-BY 3.0 License.

\section{References}

Ajami, N. K., Gupta, H., Wagener, T. and Sorooshian, S.: Calibration of a semi-distributed hydrologic model for streamflow estimation along a river system, J. Hydrol., 298(1-4), 112-135, doi:10.1016/j.jhydrol.2004.03.033, 2004.

Arabi, M., Govindaraju, R. S., Hantush, M. M. and Engel, B. A.: Role of watershed subdivision on modeling the

5 effectiveness of best management practices with SWAT, J. Am. Water Resour. Assoc., 42(2), 513-528, doi:10.1111/j.17521688.2006.tb03854.x, 2006.

Arnold, J. G., Allen, P. M. and Bernhardt, G.: A comprehensive surface-groundwater flow model, J. Hydrol., 142(1-4), 4769, doi:10.1016/0022-1694(93)90004-S, 1993.

Bathurst, J. C.: Sensitivity analysis of the Systeme Hydrologique Europeen for an upland catchment, J. Hydrol., 87(1-2),

10 103-123, doi:10.1016/0022-1694(86)90117-4, 1986.

Beven, K.: Prophecy, reality and uncertainty in distributed hydrological modelling, Adv. Water Resour., 16(1), 41-51, doi:10.1016/0309-1708(93)90028-E, 1993.

Beven, K. J.: Changing ideas in hydrology - The case of physicallybased models, J. Hydrol., 105(1-2), 157-172, doi:10.1016/0022-1694(89)90101-7, 1989.

15 Beven, K. J. . and Binley, A. M.: The future of distributed models: Model calibration and uncertainty prediction, Hydrol. Process., 6(3), 279-298, doi:10.1002/hyp.3360060305, 1992.

Bingner, R. L., Garbrecht, J., Arnold, J. G. and Srinivasan, R.: Effect of watershed subdivision on simulation runoff and fine sediment yield, Trans. Am. Soc. Agric. Eng., 40(5), 1329-1335, doi:10.13031/2013.21391, 1997.

Bongartz, K.: Applying different spatial distribution and modelling concepts in three nested mesoscale catchments of

20 Germany, Phys. Chem. Earth, Parts A/B/C, 28(33-36), 1343-1349, doi:10.1016/j.pce.2003.09.010, 2003.

Boyd, M. J., Pilgrim, D. H. and Cordery, I.: A storage routing model based on catchment geomorphology, J. Hydrol., 42(34), 209-230, doi:10.1016/0022-1694(79)90048-9, 1979.

Boyle, D. P., Gupta, H. V. and Sorooshian, S.: Toward improved calibration of hydrologic models: combining the strengths of manual and automatic methods, Water Resour. Res., 36(12), 3663-3674, doi:10.1029/2000WR900207, 2000.

25 Boyle, D. P., Gupta, H. V., Sorooshian, S., Koren, V., Zhang, Z. and Smith, M.: Towards improved streamflow forecasts: The value of semidistributed modeling, Water Resour. Res., 37(11), 2749-2759, doi:10.1029/2000WR000207, 2001.

Bruneau, P., Gascuel-Odoux, C., Robin, P., Merot, P. and Beven, K.: Sensitivity to space and time resolution of a hydrological model using digital elevation data, Hydrol. Process., 9(1), 69-81, doi:10.1002/hyp.3360090107, 1995.

Cho, H. and Olivera, F.: Effect of the Spatial Variability of Land Use, Soil Type, and Precipitation on Streamflows in Small 30 Watersheds, J. Am. Water Resour. Assoc., 45(3), 673-686, doi:10.1111/j.1752-1688.2009.00315.x, 2009.

Cho, J., Lowrance, R. R., Bosch, D. D., Strickland, T. C., Her, Y. and Vellidis, G.: Effect of watershed subdivision and filter width on SWAT simulation of a coastal plain watershed, J. Am. Water Resour. Assoc., 46(3), 586-602, doi:10.1111/j.17521688.2010.00436.x, 2010. 
Hydrol. Earth Syst. Sci. Discuss., doi:10.5194/hess-2016-627, 2016

Manuscript under review for journal Hydrol. Earth Syst. Sci.

Published: 6 December 2016

(c) Author(s) 2016. CC-BY 3.0 License.

Dehotin, J. and Braud, I.: Which spatial discretization for distributed hydrological models? Proposition of a methodology and illustration for medium to large scale catchments, Hydrol. Earth Syst. Sci., 12, 769-796, 2008.

Donnelly, C., Andersson, J. C. M. and Arheimer, B.: Using flow signatures and catchment similarities to evaluate the EHYPE multi-basin model across Europe, Hydrol. Sci. J., 61(2), 255-273, doi:10.1080/02626667.2015.1027710, 2016.

5 Eckhardt, K. and Arnold, J. G.: Automatic calibration of a distributed catchment model, J. Hydrol., 251(1-2), 103-109, doi:10.1016/S0022-1694(01)00429-2, 2001.

Efstratiadis, A. and Koutsoyiannis, D.: An evolutionary annealing-simplex algorithm for global optimisation of water resource systems, in Proceedings of the Fifth International Conference on Hydroinformatics, pp. 1423-1428, International Water Association, Cardiff, UK., 2002.

10 Efstratiadis, A. and Koutsoyiannis, D.: One decade of multiobjective calibration approaches in hydrological modelling: a review, Hydrol. Sci. J., 55(1), 58-78, doi:10.1080/02626660903526292, 2010.

Efstratiadis, A., Nalbantis, I., Koukouvinos, A., Rozos, E. and Koutsoyiannis, D.: HYDROGEIOS: a semi-distributed GISbased hydrological model for modified river basins, Hydrol. Earth Syst. Sci., 12(4), 989-1006, doi:10.5194/hess-12-9892008, 2008.

15 Efstratiadis, A., Koussis, A. D., Lykoudis, S., Koukouvinos, A. Christofides, A., Karavokiros, G., Kappos, N., Mamassis, N. and Koutsoyiannis, D.: Hydrometeorological network for flood monitoring and modeling, in Proceedings of First International Conference on Remote Sensing and Geoinformation of Environment, (SPIE), Society of Photo-Optical Instrumentation Engineers, 8795, 10-1-10-10, Paphos, Cyprus., 2013.

Efstratiadis, A., Koukouvinos, A., Michaelidi, E., Galiouna, E., Tzouka, K., Koussis, A. D., Mamassis, N. and

20 Koutsoyiannis, D.: Description of regional approaches for the estimation of characteristic hydrological quantities, DEUCALION - Assessment of flood flows in Greece under conditions of hydroclimatic variability: Development of physically-established conceptual-probabilistic, Department of Water Resources and Environmental Engineering - National Technical University of Athens, National Observatory of Athens, Athens., 2014a.

Efstratiadis, A., Koussis, A. D., Koutsoyiannis, D. and Mamassis, N.: Flood design recipes vs. reality: can predictions for ungauged basins be trusted?, Nat. Hazards Earth Syst. Sci., 14(6), 1417-1428, doi:10.5194/nhess-14-1417-2014, 2014b.

Efstratiadis, A., Koukouvinos, A., Dimitriadis, P., Rozos, E. and Koussis, A. D.: Theoretical documentation of hydrologicalhydraulic simulation model, DEUCALION - Assessment of flood flows in Greece under conditions of hydroclimatic variability: Development of physically-established conceptual-probabilistic framework and computational, Department of Water Resources and Environmental Engineering - National Technical University of Athens, National Observatory of 30 Athens, Athens., 2014c.

Fatichi, S., Vivoni, E. R., Ogden, F. L., Ivanov, V. Y., Mirus, B., Gochis, D., Downer, C. W., Camporese, M., Davison, J. H., Ebel, B., Jones, N., Kim, J., Mascaro, G., Niswonger, R., Restrepo, P., Rigon, R., Shen, C., Sulis, M. and Tarboton, D.: An overview of current applications, challenges, and future trends in distributed process-based models in hydrology, J. Hydrol., 537, 45-60, doi:10.1016/j.jhydrol.2016.03.026, 2016. 
Hydrol. Earth Syst. Sci. Discuss., doi:10.5194/hess-2016-627, 2016

Manuscript under review for journal Hydrol. Earth Syst. Sci.

Published: 6 December 2016

(c) Author(s) 2016. CC-BY 3.0 License.

FitzHugh, T. . and Mackay, D. .: Impacts of input parameter spatial aggregation on an agricultural nonpoint source pollution model, J. Hydrol., 236(1-2), 35-53, doi:10.1016/S0022-1694(00)00276-6, 2000.

Flügel, W.-A.: Delineating hydrological response units by geographical information system analyses for regional hydrological modelling using PRMS/MMS in the drainage basin of the river Brosl, Germany, Hydrol. Process., 9(1994),

5 423-436, doi:10.1002/hyp.3360090313, 1995.

Flügel, W.-A.: Combining GIS with regional hydrological modelling using hydrological response units (HRUs): An application from Germany, Math. Comput. Simul., 43, 297-304, doi:10.1016/S0378-4754(97)00013-X, 1997.

Gassman, P. W.: A Simulation Assessment of the Boone River Watershed: Baseline Calibration/Validation Results and Issues, and Future Needs, Iowa State University, Ameas, Iowa., 2008.

10 Gassman, P. W., Reyes, M. R., Green, C. H. and Arnold, J. G.: The Soil and Water Assessment Tool: Historical development, applications, and future research directions, Trans. Am. Soc. Agric. Eng., 50(4), 1211-1250, doi:10.13031/2013.23637, 2007.

Gharari, S., Hrachowitz, M., Fenicia, F. and Savenije, H. H. G.: Hydrological landscape classification: investigating the performance of HAND based landscape classifications in a central European meso-scale catchment, Hydrol. Earth Syst. Sci.,

15 15(11), 3275-3291, doi:10.5194/hess-15-3275-2011, 2011.

Gitau, M. W.: A Quantitative Assessment of BMP Effectiveness for Phosphorus Pollution Control: The Town Brook Watershed, NY, The Pennsylvannia State University, Pennsylvannia, USA., 2003.

Goodrich, D. C.: An Overview of the USDA-ARS Climate Change and Hydrology Program and Analysis of Model Complexity as a Function of Basin Scale, in Proceedings of the Workshop on the Effects of Global Climate Change on

20 Hydrology and Water Resources at Catchment Scale, pp. 233-242, Tsukuba, Japan., 1992.

Goodrich, D. C., Woolhiser, D. A. and Sorooshian, S.: Model complexity required to maintain hydrologic response, in Proceedings ASCE National Conference on Hydraulic Engineering, edited by S. A. Abt and J. Gessler, pp. 431-463, Colorado Springs CO, USA., 1988.

Han, J.-C., Huang, G.-H., Zhang, H., Li, Z. and Li, Y.-P.: Effects of watershed subdivision level on semi-distributed 25 hydrological simulations: case study of the SLURP model applied to the Xiangxi River watershed, China, Hydrol. Sci. J., 59(1), 108-125, doi:10.1080/02626667.2013.854368, 2014.

Hromadka, T. V.: San Bernardino county Hydrology Manual, Irvine, California., 1986.

Huang, M., Gallichand, J., Wang, Z. and Goulet, M.: A modification to the Soil Conservation Service curve number method for steep slopes in the Loess Plateau of China, Hydrol. Process., 589(May 2004), 579-589, doi:10.1002/hyp.5925, 2006.

30 Jakeman, A. J. and Hornberger, G. M.: How much complexity is warranted in a rainfall-runoff model?, Water Resour. Res., 29(8), 2637-2649, doi:10.1029/93WR00877, 1993.

Kalin, L., Govindaraju, R. S. and Hantush, M. M.: Effect of geomorphologic resolution on modeling of runoff hydrograph and sedimentograph, J. Hydrol., 276(1-4), 89-111, doi:10.1016/S0022-1694(03)00072-6, 2003.

Kite, G. W.: Manual for the SLURP hydrological model, Saskatoon, Canada., 1997. 
Hydrol. Earth Syst. Sci. Discuss., doi:10.5194/hess-2016-627, 2016

Manuscript under review for journal Hydrol. Earth Syst. Sci.

Published: 6 December 2016

(c) Author(s) 2016. CC-BY 3.0 License.

Kottegoda, N. T.: Stochastic water resources technology, McMillan Press, Hong Kong., 1980.

Koussis, A. D.: Assessment and review of the hydraulics of storage flood routing 70 years after the presentation of the Muskingum method, Hydrol. Sci. J., 54(1), 43-61, doi:10.1623/hysj.54.1.43, 2009.

Koussis, A. D.: Reply to the Discussion of "Assessment and review of the hydraulics of storage flood routing 70 years after

the presentation of the Muskingum method" by M. Perumal, Hydrol. Sci. J., 55(8), 1431-1441, doi:10.1080/02626667.2010.491261, 2010.

Kumar, S. and Merwade, V.: Impact of watershed subdivision and soil data resolution on SWAT model calibration and parameter uncertainty, J. Am. Water Resour. Assoc., 45(5), 1179-1196, doi:10.1111/j.1752-1688.2009.00353.x, 2009.

Leavesley, G. H. and Stannard, L. G.: The precipitation-runoff modeling system-PRMS, in Computer models of watershed

10 hydrology, edited by V. P. Singh, Water Resources Publication, Colorado., 1995.

Leavesley, G. H., Lichty, R. W., Troutman, B. M. and Saindon, L. G.: Precipitation-Runoff Modeling System: User's Manual., Denver, Colorado, USA., 1983.

Li, Z., Li, L., Huang, P. and Li, Q.: Effect of watershed subdivision on confluence parameter, J. Hohai Univ., 42(4), 283288, doi:10.3876/j.issn.1000-1980.2014.04.001, 2014.

15 Manguerra, H. B. and Engel, B. A.: Hydrologic parameterization of watersheds for runoff prediction using SWAT, J. Am. Water Resour. Assoc., 34(5), 1149-1162, doi:10.1111/j.1752-1688.1998.tb04161.x, 1998.

Mazi, K., Koussis, A. D., Restrepo, P. J. and Koutsoyiannis, D.: A groundwater-based, objective-heuristic parameter optimisation method for the PRMS model: The Akrotiri Basin, Cyprus application, J. Hydrol., 290(3), 243-258, doi:10.1016/j.jhydrol.2003.12.006, 2004a.

20 Mazi, K., Koussis, A. D., Restrepo, P. J. and Koutsoyiannis, D.: Erratum: A groundwater-based, objective-heuristic parameter optimisation method for the PRMS model: The Akrotiri Basin, Cyprus application, J. Hydrol., 299(1-2), 160-161, 2004b.

Molnar, D. K. and Julien, P. Y.: Grid-size effects on surface runoff modeling, J. Hydrol. Eng., 5(1), 8-16, doi:10.1061/(ASCE)1084-0699(2000)5:1(8), 2000.

25 Muleta, M. K., Nicklow, J. W. and Bekele, E. G.: Sensitivity of a distributed watershed simulation model to spatial scale, J. Hydrol. Eng., 12(2), 163-172, 2007.

Nalbantis, I., Efstratiadis, A., Rozos, E., Kopsiafti, M. and Koutsoyiannis, D.: Holistic versus monomeric strategies for hydrological modelling of human-modified hydrosystems, Hydrol. Earth Syst. Sci., 15(3), 743-758, doi:10.5194/hess-15743-2011, 2011.

30 Nash, J. E. and Sutcliffe, J. V.: River flow forecasting through conceptual models part I - A discussion of principles, J. Hydrol., 10(3), 282-290, doi:10.1016/0022-1694(70)90255-6, 1970.

Neitsch, S. L., Arnold, J. G., Kiniry, J. R., Williams, J. R. and King, K. W.: Soil and Water Assessment Tool Theoretical Documentation, Version 2000, Temple, Texas, USA., 2002. 
Hydrol. Earth Syst. Sci. Discuss., doi:10.5194/hess-2016-627, 2016

Manuscript under review for journal Hydrol. Earth Syst. Sci.

Published: 6 December 2016

(c) Author(s) 2016. CC-BY 3.0 License.

Neitsch, S. L., Arnold, J. G., Kiniry, J. R. and Williams, J. R.: Soil and Water Assessment Tool Theoretical Documentation, Version 2005, Temple, Texas, USA., 2005.

Norris, G. R.: A proccess for interfacing a hydrologic model to a geographic information system, Oklahoma State University - Stillwater., 1992.

5 Norris, G. R. and Haan, C. T.: Impact of subdivining watersheds on estimated hydrographs, Am. Soc. Agricutlural Eng., 9(5), 443-445, doi:10.13031/2013.26007, 1993.

Nour, M. H., Smith, D. W., El-Din, M. G. and Prepas, E. E.: Effect of watershed subdivision on water-phase phosphorus modelling: An artificial neural network modelling application, J. Environ. Eng. Sci., 7(S1), 95-108, doi:10.1139/S08-043, 2008.

10 NRCS: SCS National Engineering Handbook, Section 4, Washington, DC., 1972.

Refsgaard, J. C.: Parameterisation, calibration and validation of distributed hydrological models, J. Hydrol., 198(1-4), 6997, doi:10.1016/S0022-1694(96)03329-X, 1997.

Reggiani, P. and Rientjes, T. H. M.: Flux parameterization in the representative elementary watershed approach: application to a natural basin, Water Resour. Res., 41(4), 1-18, doi:10.1029/2004WR003693, 2005.

15 Reggiani, P., Sivapalan, M. and Hassanizadeh, S. M.: A unifying framework for watershed thermodynamics: balance equations for mass, momentum, energy and entropy, and the second law of thermodynamics, Adv. Water Resour., 22(4), 367-398, doi:10.1016/S0309-1708(98)00012-8, 1998.

Reggiani, P., Hassanizadeh, S. M., Sivapalan, M. and Gray, W. G.: A unifying framework for watershed thermodynamics: constitutive relationships, Adv. Water Resour., 23(1), 15-39, doi:10.1016/S0309-1708(99)00005-6, 1999.

20 Reggiani, P., Sivapalan, M. and Hassanizadeh, S. .: Conservation equations governing hillslope responses: exploring the physical basis of water balance, Water Resour. Res., 36(7), 1845-1863, doi:10.1029/2000WR900066, 2000.

Rennó, C. D., Nobre, A. D., Cuartas, L. A., Soares, J. V., Hodnett, M. G., Tomasella, J. and Waterloo, M. J.: HAND, a new terrain descriptor using SRTM-DEM: Mapping terra-firme rainforest environments in Amazonia, Remote Sens. Environ., 112(19), 3469-3481, doi:10.1016/j.rse.2008.03.018, 2008.

25 Rozos, E. and Koutsoyiannis, D.: A multicell karstic aquifer model with alternative flow equations, J. Hydrol., 325(1-4), 340-355, doi:10.1016/j.jhydrol.2005.10.021, 2006.

Rozos, E., Efstratiadis, A., Nalbantis, I. and Koutsoyiannis, D.: Calibration of a semi-distributed model for conjunctive simulation of surface and groundwater flow, Hydrol. Sci. J., 49(5), 819-842, doi:10.1623/hysj.49.5.819.55130, 2004.

Sasowsky, K. C. and Gardner, T. W.: Watershed configuration and geographic information system parameterization for

30 SPUR model hydrologic simulations, J. Am. Water Resour. Assoc., 27(1), 7-18, doi:10.1111/j.1752-1688.1991.tb03108.x, 1991.

Savenije, H. H. G.: HESS Opinions “Topography driven conceptual modelling (FLEX-Topo),” Hydrol. Earth Syst. Sci., 14(12), 2681-2692, doi:10.5194/hess-14-2681-2010, 2010. 
Hydrol. Earth Syst. Sci. Discuss., doi:10.5194/hess-2016-627, 2016

Manuscript under review for journal Hydrol. Earth Syst. Sci.

Published: 6 December 2016

(c) Author(s) 2016. CC-BY 3.0 License.

Srinivasan, R., Muttiah, R. S., Dyke, P. T., Walker, C. and Arnold, J.: Hydrologic unit model for the United States (HUMUS), Temple, TX., 2000.

Tao, T. and Kouwen, N.: Remote sensing and fully distributed modelling for flood forecasting, edited by B. C. Yen, J. Water Resour. Plan. Manag., 115(6), 809-823, doi:10.1061/(ASCE)0733-9496(1989)115:6(809), 1989.

5 Tegos, A., Efstratiadis, A. and Koutsoyiannis, D.: A parametric model for potential evapotranspiration estimation based on a simplified formulation of the Penman-Monteith equation, in Evapotranspiration - An Overview, edited by S. G. Alexandris, p. 24, InTech., 2013.

Thieken, A. H., Lücke, A., Diekkrüger, B. and Richter, O.: Scaling input data by GIS for hydrological modelling, Hydrol. Process., 13(4), 611-630, doi:10.1002/(SICI)1099-1085(199903)13:4<611::AID-HYP758>3.0.CO;2-6, 1999.

10 Tsoukalas, I., Kossieris, P., Efstratiadis, A. and Makropoulos, C.: Surrogate-enhanced evolutionary annealing simplex algorithm for effective and efficient optimization of water resources problems on a budget, Environ. Model. Softw., 77, 122142, doi:10.1016/j.envsoft.2015.12.008, 2016.

Wagener, T., Boyle, D. P., Lees, M. J., Wheater, H. S., Gupta, H. V. and Sorooshian, S.: A framework for development and application of hydrological models, Hydrol. Earth Syst. Sci., 5(1), 13-26, doi:10.5194/hess-5-13-2001, 2001.

15 Winchell, M., Srinivasan, R., Di Luzio, M. and Arnold, J. G.: ArcSwat Interface For SWAT 2012: Users Guide, Temple, Texas, USA., 2013.

Wood, E. F., Sivapalan, M., Beven, K. and Band, L.: Effects of spatial variability and scale with implications to hydrologic modeling, J. Hydrol., 102(1-4), 29-47, doi:10.1016/0022-1694(88)90090-X, 1988.

Xu, Y., Fu, B., Gao, G. and He, C.: Watershed discretization based on multiple factors and its application in the Chinese

20 Loess Plateau, Hydrol. Earth Syst. Sci., 8(5), 9063-9087, doi:10.5194/hess-16-59-2012, 2011.

Zhang, H. L., Wang, Y. J., Wang, Y. Q., Li, D. X. and Wang, X. K.: The effect of watershed scale on HEC-HMS calibrated parameters: a case study in the Clear Creek watershed in Iowa, US, Hydrol. Earth Syst. Sci., 17(7), 2735-2745, doi:10.5194/hess-17-2735-2013, 2013.

Zhang, W. and Montgomery, D. R.: Digital elevation model grid size, landscape representation, and hydrologic simulations,

25 Water Resour. Res., 30(4), 1019-1028, doi:10.1029/93WR03553, 1994.

Zhang, Z., Koren, V., Smith, M., Reed, S. and Wang, D.: Use of next generation weather radar data and basin disaggregation

to improve continuous hydrograph simulations, J. Hydrol. Eng., 9(2), 103-115, doi:10.1061/(ASCE)10840699(2004)9:2(103), 2004. 